\title{
The gender pay gap in university student employment
}

\author{
Paul David Boll ${ }^{1} \cdot$ Lukas Mergele $^{2} \cdot{\text { Larissa } \text { Zierow }^{2}}^{2}$
}

Received: 7 March 2021 / Accepted: 11 November 2021 / Published online: 27 January 2022

(c) The Author(s) 2022, corrected publication 2022

\begin{abstract}
Gender pay gaps are commonly studied in populations with already completed educational careers. We focus on an earlier stage by investigating the gender pay gap among university students working alongside their studies. With data from five cohorts of a large-scale student survey from Germany, we use regression and wage decomposition techniques to describe gender pay gaps and potential explanations. We find that female students earn about $6 \%$ less on average than male students, which reduces to $4.1 \%$ when accounting for a rich set of explanatory variables. The largest explanatory factor is the type of jobs male and female students pursue.
\end{abstract}

Keywords Gender pay gap · University student employment · Job types

JEL Classification I22 $\cdot$ I23 $\cdot \mathrm{J} 16 \cdot \mathrm{J} 31$

\section{Introduction}

A vast literature investigates the causes of pay gaps between men and women. Explanations range from differences in occupational and industry choice to differences in personality and attitudes. The question of when pay differences begin to manifest themselves has received far less attention: Most studies look at pay gaps in labor market outcomes at a point in workers' lives at which they have already completed their education. ${ }^{1}$ This leaves out earlier, smaller-scale employment before the entry into the general labor market, which may offer important insights into the origins of gender pay gaps.

\footnotetext{
1 An example is the literature on "child penalties": For instance, Kleven et al. (2019) document that parenthood widens the gender gap in earnings by around $20 \%$.

$\bowtie \quad$ Lukas Mergele mergele@ifo.de

1 University of Warwick, Coventry, UK

2 ifo Institute, CESifo, University of Munich, Munich, Germany
} 
In this paper, we examine the gender pay gap in university student employment. Being the first to investigate gender pay gaps in this setting, we use data from a largescale student survey from Germany, which includes rich information on employment, socioeconomic background, living situation, study characteristics, high school performance and personality factors. This allows us to use regression analyses with an extensive battery of covariates to quantify the unexplained gender pay gap among students and seek potential explanations for it. We also derive stylized facts about its relation to differences in the field of study and the job types male and female students pursue.

We find an unconditional gender pay gap in hourly wages of about $6 \%$, which reduces to about $4.1 \%$ after accounting for a wide range of student characteristics. This unexplained gap is robust to a range of different regression specifications and sample restrictions. We find large variation in the pay gap across different job types, as well as significant gender selection differences into these job types: Males are more likely to work in jobs that are related to their studies, whereas females are more likely to pursue jobs which require less or no subject knowledge.

The student setting is relevant to the gender pay gap literature as it reduces the importance of other factors which have been found to induce gender pay gaps later in life, for example family-formation decisions in the studies of, among others, Kleven et al. (2019), Bütikofer et al. (2018) and Albrecht et al. (2018). Following this idea, Francesconi and Parey (2018), Leuze and Strauss (2014) as well as Reimer and Schröder (2006) analyze starting salaries of German graduates and still find substantial gender gaps. We take this approach one step further by examining the difference in wages between genders for university students currently enrolled in university. Many student occupations differ decidedly from a general labor market setting. A majority of students is employed part-time, in jobs often unrelated to their education, earning relatively low wages. Being the first paper to apply gender pay gap analysis to the university setting is one of our major contributions. Our descriptive analyses shed new light on when gender differences in pay emerge and which factors may explain them. Additionally, our analyses contribute to the gender pay gap literature by providing new insights into gender differences in work experience before graduation. Existing literature usually defines work experience as the time spent working since graduation, omitting previous experience as a potential channel for gender pay gaps. Yet, this channel may be crucial if working experience matters for students' success in later recruitment processes and wage negotiations. Moreover, as Auspurg et al. (2017) shows, the expectations of men and women for both sexes' earnings are shaped by specific experiences in the labor market. If already university students experience gender wage gaps, this can contribute early to status beliefs and social constructions which foster gender wage inequality in the long run (Auspurg et al. 2017).

Besides studying the gender pay gap in this new setting, our paper contributes to the existing literature in four ways: First, we investigate the selection of students into working and different types of student jobs. In doing so, we document significant male-female differences in the type of jobs students choose to pursue alongside their studies. We thus extend the finding by Blau and Kahn (2017) who document that gender differences in occupations and industries continue to explain a significant part of the wage gap at later career stages. Second, a more recent strand of literature investigates 
the wage effects of psychological and attitudinal factors like gender differences in risk preferences, competitiveness, attitudes toward negotiation and career expectations (see Bertrand (2011) for a review). We provide suggestive evidence that gender wage gaps in the student environment are higher in jobs with plausibly larger scope for wage negotiation. Third, a growing literature addresses the labor market returns to different college majors: Altonji et al. (2016) find large effects of college major choice on future earnings, and Ochsenfeld (2014) shows that men choose more often majors which have higher-paid jobs after finishing studies. Our paper contributes to this by investigating gender pay gaps and their relationship to gender differences in major choice. However, our findings suggest that student wages differ little across fields of study. Fourth, by analyzing gender gaps in student jobs, our findings complement recent studies documenting gender gaps in wage expectations of university students, such as Briel et al. (2021), Kiessling et al. (2019) and Reuben et al. (2017).

Germany is a compelling setting to advance this research for three reasons: First, its raw gender pay gap of 21\% in 2018 (Destatis 2019) is one of the highest among OECD countries. Second, as in many other countries including the US, it is common for students to work alongside their studies. In 2016, 68\% of German university students were working during term time (Middendorff et al. 2017), the highest share out of any European country and higher than the 2018 US share of $43 \%$ (Hussar et al. 2020). Third, German students spend a comparatively long time at university, with $60 \%$ of undergraduate students subsequently enrolling in a postgraduate program. Consequently, students who work throughout their studies gain significant work experience, which may be relevant for later labor market outcomes.

The remainder of this paper is organized as follows. Section 2 briefly presents some institutional background on the German setting. Section 3 discusses our data and methodological strategy and presents summary statistics of important variables. In Sect. 4, we present the empirical results, discuss some robustness checks and investigate important channels. Section 5 concludes.

\section{Institutional background on student employment in the German higher education system}

According to Hauschildt et al. (2018), Germany has the largest share of university students working in regular paid jobs during term time within Europe. Middendorff et al. (2017) find that in 2016, roughly $68 \%$ of the German student population was employed during lecture periods, up from $62 \%$ in 2012. In 2018, the share of working students in the US was $43 \%$ (Hussar et al. 2020). Furthermore, there are gender differences in German student employment: In 2016, 70\% of female students were working versus only $66 \%$ of male students. A compelling feature of German higher education and the student job market is the institution of student assistants at German universities. In contrast to US and UK universities, where graduate students occupy most student assistant positions, in Germany these positions are commonly held by undergraduates: In our sample, $28 \%$ of working Bachelor's students worked as student 
assistants. ${ }^{2}$ This allows many German students to gain practical research experience and often provides a pathway for undergraduates into Master's and $\mathrm{PhD}$ programs.

A major reason for high rates of student employment is that study durations in Germany are comparatively long, with $60 \%$ of Bachelor's graduates subsequently enrolling in Master's programs. Even though standard durations of Bachelor's and Master's degrees add up to 5 years, in practice, the average time to degree is 6 years for students completing both a Bachelor's and a Master's degree (Autorengruppe Bildungsberichterstattung 2020). Thus, students need to cover their living expenses for a substantial duration while also forgoing practical work experiences. Working alongside their studies offers students a path to address these issues.

Student employment as a funding source is also important as private student loans and public financing schemes are extremely uncommon. A publicly subsidized financing scheme exists only for students from low-income families, supporting well below $20 \%$ of the student population (Garritzmann 2016, p. 78). Tuition fees are a secondary reason for students to work. Most German universities are public institutions that do not charge tuition fees, although most of them charge an administrative fee of around 300 Euros per semester. About $15 \%$ of students are enrolled in non-public institutions that may charge tuition fees (Autorengruppe Bildungsberichterstattung 2020). Hence, in the classification of Garritzmann (2016), Germany belongs to the group of "low-tuition low-subsidy" countries where student employment is particularly common. Countries that also belong to this group include Austria, Belgium, France, Italy, Spain, Switzerland and Mexico.

\section{Data and methods}

We pool student-level data from five waves (2003, 2006, 2009, 2012, 2016) of the Social Survey ( "Sozialerhebung”), conducted by the German Center for Higher Education Research and Science Studies on behalf of the Deutsches Studentenwerk (DOI: https://doi.org/10.21249/DZHW:ssypool:1.0.1). The purpose of this survey is to monitor the social and economic situation of university students in Germany. First conducted in 1951, it is the most comprehensive German survey of its kind. ${ }^{3}$ Questionnaires are sent to a random set of students from each of the participating institutions of higher education. These participating institutions account for roughly $90 \%$ of the German student population. Data provided by the survey include information on biographical and educational background, field of study, employment and income and, in recent years, personality traits. These data are thus the most comprehensive large-scale dataset for conducting research related to Germany's university students. Its sample size, its coverage of many cohorts, and its focus on university students make it more suitable to our research question than the Socio-Economic Panel (SOEP) or the National Educational Panel Study (NEPS).

\footnotetext{
${ }^{2}$ German universities distinguish between student assistants ("Studentische Hilfskräfte") and research assistants ("Wissenschaftliche Hilfskräfte"), the main difference being that research assistants are required to hold an academic degree.

3 The waves 2003 through 2016 include between 15,000 and 55,000 students each.
} 
We restrict our main analysis sample to those students belonging to the reference group "focus type" defined by the 2016 Social Survey data set. "Focus type" students are enrolled in a full-time program at an institution of higher education, are studying for their first or second higher education degree, are living alone or providing only for themselves and are not married. This restriction follows the approach chosen by the publishers of the data set themselves: In their summary report of the 2016 survey, all analyses surrounding students' economic situation are performed on this subsample of students, in order to ensure comparability of students with respect to their financial situation (Middendorff et al. 2017). We consider this restriction particularly important for our purposes, since it should significantly reduce the influence of wage determinants such as employment history or familial factors, which we do not observe. Data from the four waves covering 2003-2012, which do not yet include the "focus type" definition, are sampled according to the same criteria. ${ }^{4}$ Section A.1 discusses further sample restrictions and potential concerns due to missing data. Based on these restrictions, the sample for our main wage analysis contains 19,024 observations.

Our outcome variable is $(\log )$ net hourly wage, which is the wage variable included in the data. Usually, the pay gap literature uses monthly or yearly labor income, divided by the respective contracted hours of work. In the student setting, however, working hours are much more varied and contracts usually specify the hourly wage, so that the self-reported hourly wage is a more reliable measure. Furthermore, it is more common to use gross instead of net wages. However, this does not pose a major problem for at least two reasons. First, the majority of students, especially in the "focus type" subset, should be very similar in terms of taxes and other wage deductions, and second, there is evidence by Granados and Geyer (2013) that using net hourly wages yields a lower bound for potential wage gaps. Nevertheless, we show that the results are robust to restricting the sample to students who work less than five hours per week, in which case there are no significant tax or social security deductions.

Table 1 presents descriptive statistics for the outcome variable, net hourly wage and the major control variables (see Table A1 in the appendix for all variables). The first row shows a raw wage gap of about $7.5 \%,{ }^{5}$ as well as significant gender differences in several other variables. As documented in previous research, men are overrepresented in the natural sciences and engineering, and women are overrepresented in all other fields, most notably in the humanities. Moreover, there are significant differences in the types of jobs male and female students pursue: Men more often work as student or research assistants and are more often self-employed, whereas women are more likely to have more traditional part-time jobs like working as waiters, cashiers or office assistants (aggregated in the "Jobbing" category). ${ }^{6}$ Women also more often work as private tutors.

\footnotetext{
4 "Focus type" students make up roughly half of the respondents in each wave. We relax the restriction on "focus type" students in a robustness check by including also other types of students, which does not alter our main results. For details on further sample restrictions and corresponding robustness checks see the Appendix.

5 This is a pooled estimate across the survey waves, without including survey wave fixed effects.

6 This aggregation is present in the raw data, therefore we are not able to disaggregate these jobs further.
} 
In our main analysis, we employ multiple regression models with heteroskedasticityrobust standard errors, which have the form

$$
\ln w_{i}=\alpha+\beta \text { female }_{i}+X_{i}^{\prime} \gamma+\sum_{j=1}^{5} \alpha_{j} \text { wave }_{i j}+\epsilon_{i}
$$

where $\ln w_{i}$ is the log hourly wage variable and female $i$ indicates females, so that $\beta$ represents the adjusted wage gap in $\log$ points and is therefore our coefficient of interest. wave $i j$ indicates if student $i$ is part of survey wave $j$, therefore $\alpha_{j}$ captures survey wave fixed effects. $X_{i}$ is a vector of control variables for student $i$ which are grouped and introduced successively: First, age group dummies, second, additional socio-demographic controls like previous education and socioeconomic background, third, field of study and type of degree and fourth, controls for the type of job held. The assumption driving our strategy is the conditional independence assumption: We assume that we observe all variables which are correlated with both the outcome and the gender variable. This allows us to interpret $\beta$ as the adjusted gender wage gap. Though a strong assumption, it is supported by the observation that the estimate of $\beta$ changes very little as more controls are introduced (see Table 2). The regression results are further corroborated by Kitagawa-Oaxaca-Blinder ${ }^{7}$ decompositions (see Tables A7, A8, A9, A10).

\section{Results}

\subsection{Evidence on gender pay gaps in university student employment}

Table 2 shows the estimation results from four subsequent regressions of log net hourly wage on the gender dummy. From column (1) to (5), we include an increasing number of control variables. The female coefficient, displayed in the first row, represents the respective estimate for the gender wage gap in log points. As shown in column (1), controlling only for survey wave fixed effects yields an estimate of $6 \log$ points for the raw wage gap. However, Table A1 in the appendix shows significant differences in the age structure between male and female students in our sample. Male students tend to be older than female students raising concerns about age effects on the wage. Thus, column (2) adds age group dummies, which reduces the gap to $4.7 \log$ points. As shown in column (3), adding East German background, foreign nationality, previous vocational training and parents' professional qualification as further socio-demographic controls has little impact on the gap. Controlling for the type of degree, study abroad experience, the type of university and the field of study in column (4) even marginally increases the gap. However, controlling for the type of job in column (5) marginally reduces the gap to $4.1 \log$ points. Across all specifications, the gap is highly significant. Table A7 in the appendix shows the results from a Kitagawa-Oaxaca-Blinder decomposition using the full set of covariates from column (5). As in Table 2, the

\footnotetext{
7 Also referred to as Oaxaca-Blinder decomposition. We use the long form as the general methodology was developed by Evelyn M. Kitagawa in 1955.
} 


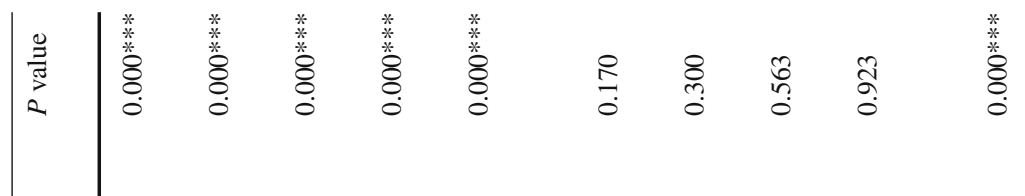

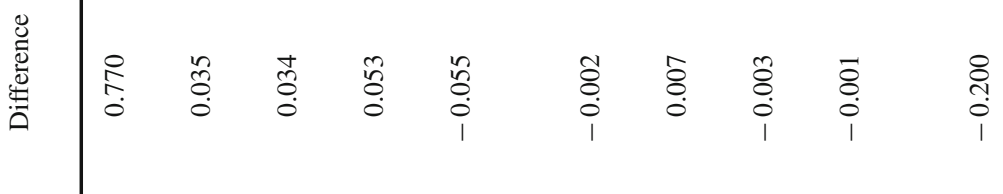

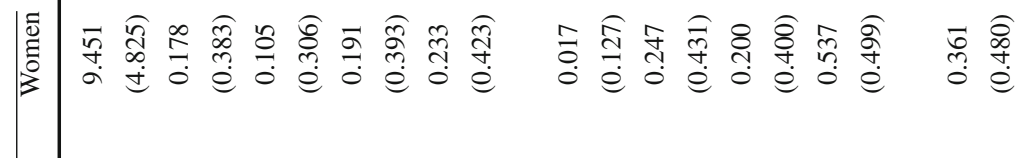

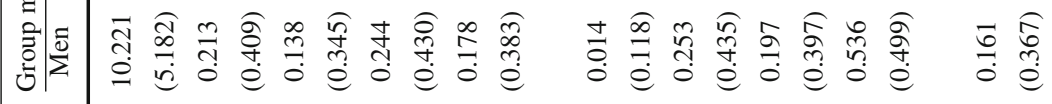

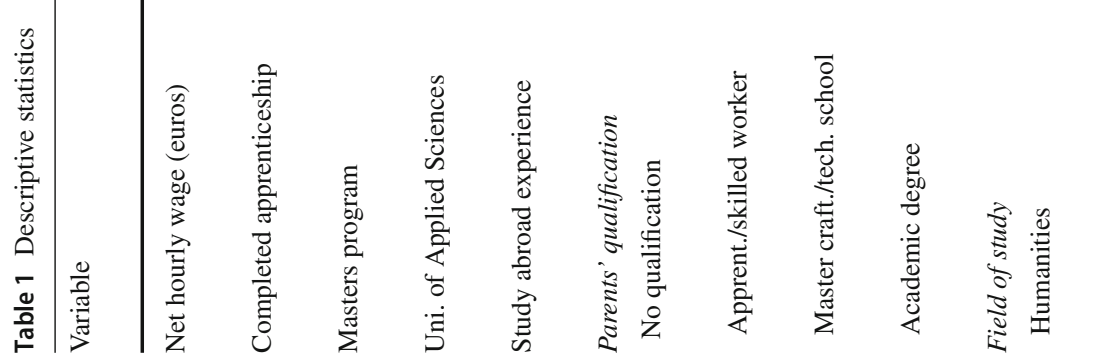




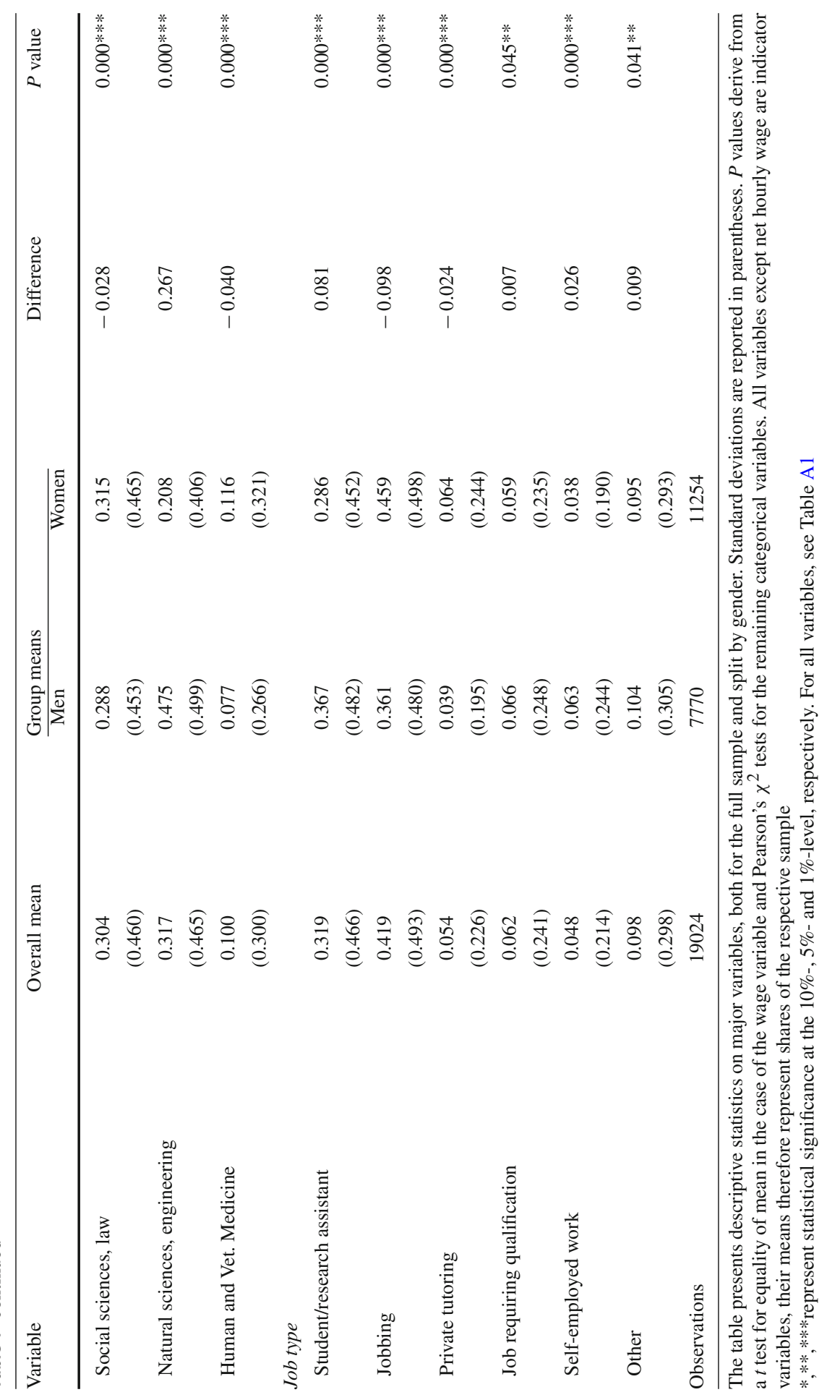


unexplained gap according to the decomposition equals $4.1 \log$ points. These results imply that a female student would earn about $4.1 \%$ less than a male student with otherwise identical observable characteristics.

These simple regressions document some highly significant factors explaining wage differences. In line with previous research, we find that wages are significantly lower for students living in East Germany, approximated by the location of their university, and students who grew up in East Germany, approximated by the location of their high school. Furthermore, wages are also increasing with the socioeconomic status of students, as measured by their parents' highest professional qualification. Unsurprisingly, students studying for a Master's degree also earn significantly more than those studying for their first degree. Yet, some of this difference seems to be captured by differences in job types in column (4). Moreover, students who have spent part of their studies abroad earn higher wages than those who have not, although this may be driven by differences in ability or motivation.

Interestingly, there is no significant variation in wages across different fields of study. ${ }^{8}$ At first, this seems to contradict previous research into labor market returns to college majors (for example Altonji et al. 2016). However, the observed differences in the general labor market may not materialize in the students' job market for several reasons: First, some student jobs may be relatively unspecific in the skills or qualifications they require. Second, potential wage advantages of certain fields of study, such as natural sciences and engineering or medicine, may be offset by the higher demands these fields place on students' time, diminishing their ability to work more time intensive, higher-paying jobs. Third, students may be more likely to work in jobs with fixed wages, for example legally set wages in the public sector or standardized wage rates for students in private businesses, preventing wage discrimination by study field. We further discuss a similar issue in Sect. 4.3.

As can be seen in the large increase in the R-squared from column (4) to column (5) ( 0.128 to 0.227 ), the single most important factor for explaining variation in students' wages is the type of job pursued. With student/research assistant jobs as the base category, on average we find that working in the "Jobbing" category decreases the wage by $4.6 \log$ points, whereas working as a private tutor or in a job requiring previous qualification increases the wage by roughly $24 \log$ points. Self-employment is associated with a $29.4 \log$ points increase. Relating this to Table 1, which shows the gender differences with respect to the types of jobs held, highlights one explanation for gender differences in student wages: Women are highly overrepresented in the lowerpaid "Jobbing" category and underrepresented in the higher-paid categories (except private tutoring). Table A7 confirms this: The job type variable accounts for roughly one-third (0.9 log points) of the explained component of the gap (2.7 log points).

We further test the robustness of our results by relaxing the "focus type" sample restriction discussed in Sect. 3. To alleviate potential sample selection concerns, we run the full specification wage regression from Table 2, column (5) in a larger sample which includes focus-type and non-focus-type students. Detailed results can be found

\footnotetext{
8 We repeat the regression analysis without the variable controlling for the type of university: Since Universities of Applied Sciences usually cover a different range of subjects to regular universities, including this variable may obscure wage variation across study fields. However, as shown in Table A13, the results are only minimally affected by this change.
} 


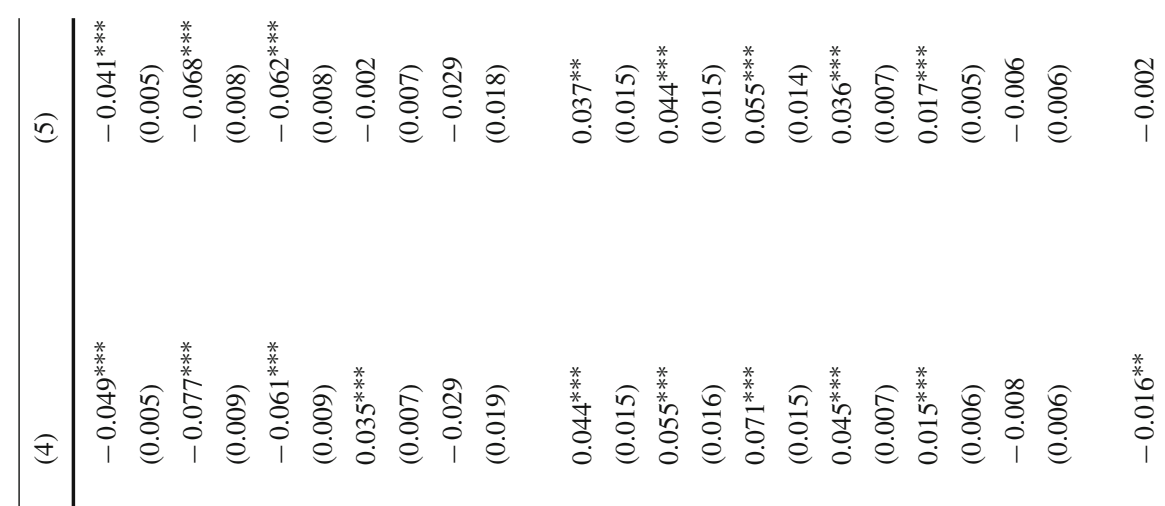

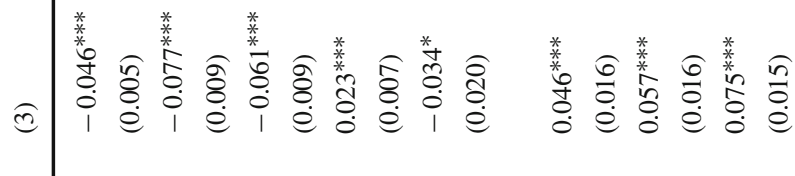

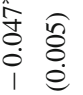

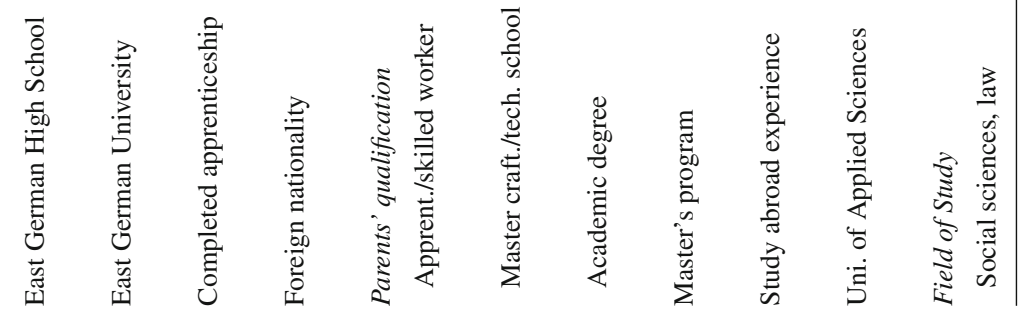




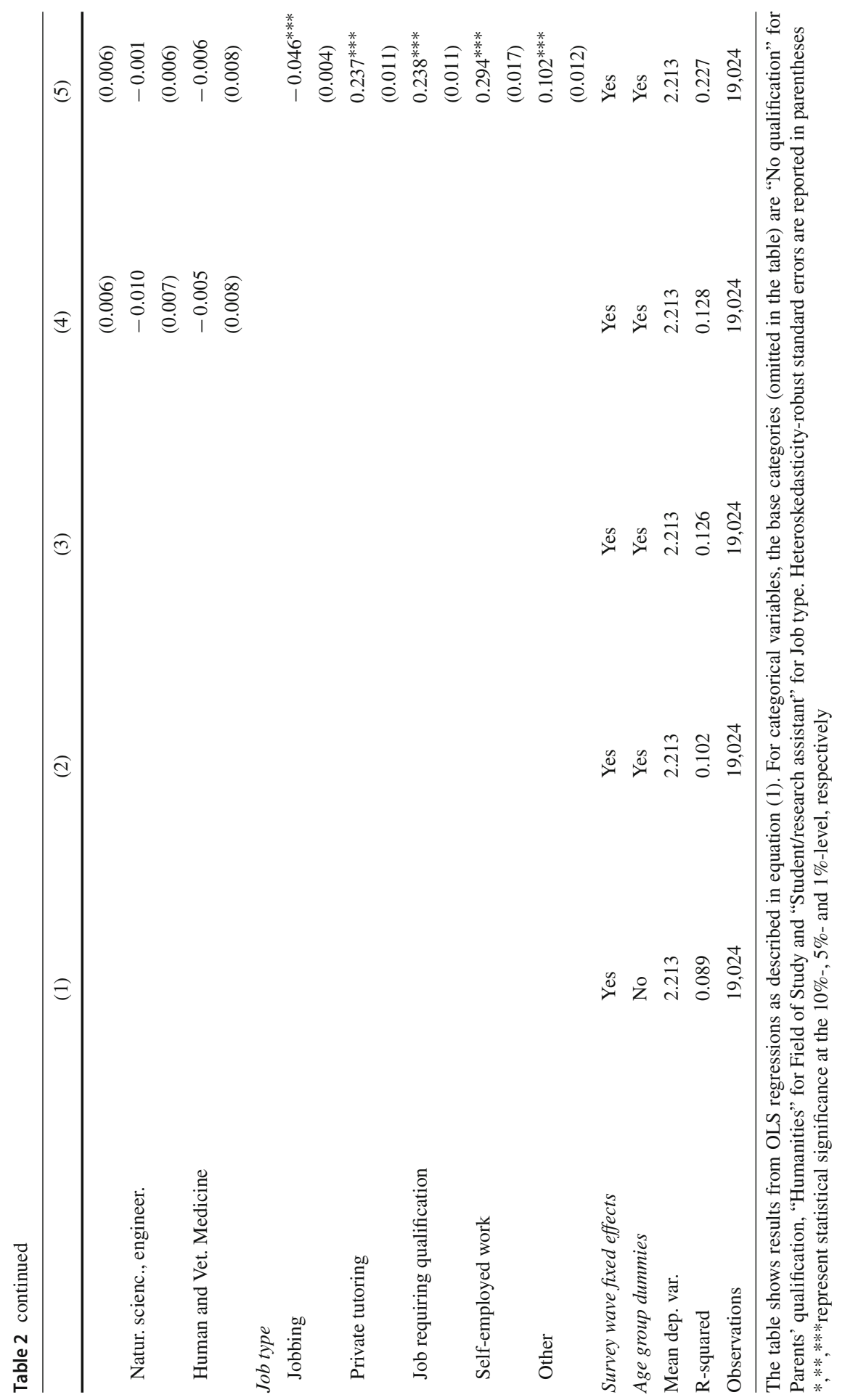


in Table A3, column (1) in the appendix. The female coefficient only marginally changes to $3.6 \log$ points and remains significantly different from zero at the $1 \%$ level, suggesting strong robustness of our main result.

As explained in Sect. 3, there are potential concerns about using net wages instead of gross wages in our analyses, as results may be biased by non-random distribution of wage deductions. We address these concerns by running our full wage regression in a sample restricted to students who work five hours or less per week. In Germany, jobs paying a monthly income of 450 Euros or less are practically exempt from taxes and most social security deductions. Therefore, this sample restriction should eliminate most of the potential bias. Table A3, column (3) in the appendix shows the results. The female coefficient for the restricted sample increases in absolute value to 4.7 $\log$ points, suggesting that if there is any bias stemming from net wages in our main sample, it attenuates rather than exaggerates the gap.

Finally, one may suspect gender differences in the time spent working or in disposable income from other sources to be driving the gap. These income sources may include parents, government loans or grants and scholarships. The reasons we do not include these variables in our main specification are twofold: First, there are reverse causality concerns. For example, higher wages could incentivize students to work longer hours via a substitution effect, or to work shorter hours via an income effect. Parents may reduce their financial support if their children earn more money working. Second, we only observe these variables for a subset of students. Table A4 in the appendix shows detailed results of adding them to our full wage regression (Table A10 shows the results from the respective Kitagawa-Oaxaca-Blinder decomposition). The resulting female coefficient equals $4.0 \mathrm{log}$ points, which is very close to the main coefficient in Table 2, column (5).

\subsection{The relevance of ability and personality}

The 2016 wave of the Social Survey includes a more extensive set of questions enabling us to investigate the role of ability and personality for the gender wage gap across students. As noted by Blau and Kahn (2017), personality traits have been found to be an important explanatory factor in pay gap analyses. Personality is measured along the Big Five personality dimensions and an additional dimension of self-efficacy. We use students' high school grade point average as a proxy for ability. In addition, we include a variable from the 2016 wave capturing the extent to which a student's job is related to their studies.

Table 3 shows the results of successively adding these new controls to the full specification from Table 2. Sample size is significantly reduced because the relevant questions do not feature in the 2003 through 2012 waves and were only answered by a subset of respondents in the 2016 wave. The female coefficient is very stable across the four specifications (about $5.5 \mathrm{log}$ points), supporting the robustness of our qualitative results. Columns (2) through (4) show that our ability measure is not significantly related to wages. The study-relatedness of a job correlates positively with wages (columns (3) and (4)). Column (4) shows that neither self-efficacy nor the Big Five measures explain variation in wages, with the exception of a significant $1.6 \mathrm{log}$ 
Table 3 Linear wage regressions with ability and personality controls (wave 2016)

\begin{tabular}{|c|c|c|c|c|}
\hline & (1) & (2) & (3) & (4) \\
\hline Female & $\begin{array}{l}-0.055^{* * *} \\
(0.011)\end{array}$ & $\begin{array}{l}-0.055^{* * *} \\
(0.012)\end{array}$ & $\begin{array}{l}-0.053^{* * *} \\
(0.011)\end{array}$ & $\begin{array}{l}-0.055^{\text {*** }} \\
(0.013)\end{array}$ \\
\hline \multicolumn{5}{|l|}{ High school GPA } \\
\hline Very good & & $\begin{array}{l}-0.107 \\
(0.079)\end{array}$ & $\begin{array}{l}-0.110 \\
(0.079)\end{array}$ & $\begin{array}{l}-0.112 \\
(0.078)\end{array}$ \\
\hline Good & & $\begin{array}{l}-0.088 \\
(0.078)\end{array}$ & $\begin{array}{l}-0.088 \\
(0.079)\end{array}$ & $\begin{array}{l}-0.092 \\
(0.078)\end{array}$ \\
\hline Satisfactory & & $\begin{array}{l}-0.090 \\
(0.078)\end{array}$ & $\begin{array}{l}-0.090 \\
(0.079)\end{array}$ & $\begin{array}{l}-0.096 \\
(0.078)\end{array}$ \\
\hline Job study- related & & & $\begin{array}{l}0.036^{* * *} \\
(0.013)\end{array}$ & $\begin{array}{l}0.037^{* * *} \\
(0.013)\end{array}$ \\
\hline Self-efficacy & & & & $\begin{array}{l}-0.006 \\
(0.011)\end{array}$ \\
\hline \multicolumn{5}{|l|}{ Big Five personality } \\
\hline Agreeableness & & & & $\begin{array}{l}0.010 \\
(0.007)\end{array}$ \\
\hline Conscientiousness & & & & $\begin{array}{l}-0.001 \\
(0.007)\end{array}$ \\
\hline Openness & & & & $\begin{array}{l}0.002 \\
(0.005)\end{array}$ \\
\hline Neuroticism & & & & $\begin{array}{l}-0.004 \\
(0.007)\end{array}$ \\
\hline Extraversion & & & & $\begin{array}{l}0.016^{* * *} \\
(0.005)\end{array}$ \\
\hline Age group dummies & Yes & Yes & Yes & Yes \\
\hline Further demographic controls & Yes & Yes & Yes & Yes \\
\hline Study characteristics & Yes & Yes & Yes & Yes \\
\hline Job types & Yes & Yes & Yes & Yes \\
\hline Mean dep. var. & 2.354 & 2.354 & 2.354 & 2.354 \\
\hline$R$-squared & 0.126 & 0.127 & 0.130 & 0.134 \\
\hline Observations & 2780 & 2780 & 2780 & 2780 \\
\hline
\end{tabular}

The table shows results from OLS regressions as described in equation (1). The omitted base category for High school GPA is "Sufficient." Heteroskedasticity-robust standard errors are reported in parentheses $*, * *, * * *$ represent statistical significance at the $10 \%-, 5 \%$ - and $1 \%$-level, respectively

point coefficient on extraversion. Table A8 in the appendix shows the results from a Kitagawa-Oaxaca-Blinder decomposition using the full set of covariates from column (4). 


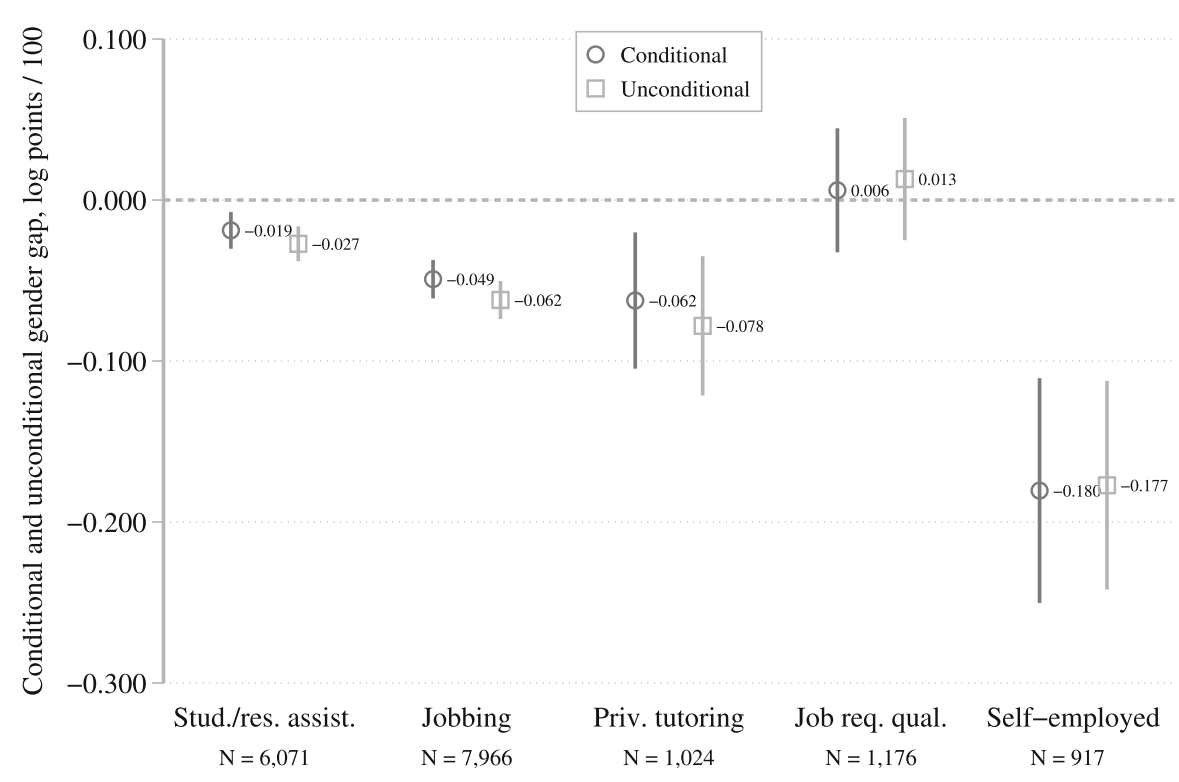

Fig. 1 The gender pay gap across job types. Notes The figure presents point estimates and 95\%-level confidence intervals for the female coefficient $\beta$ from separate wage regressions of the form described in equation (1) in the respective job type subsample. The coefficients labeled "conditional" stem from regressions using the full set of controls (see Table A5 for full results), the coefficients labeled "unconditional" stem from regressions that only control for survey wave fixed effects. Confidence intervals are computed using heteroskedasticity-robust standard errors

\subsection{The gender pay gap across job types}

Job types are a significant factor influencing wage variation and the gender wage gap as Table 2 shows. We investigate this further by performing wage regressions for different subsamples defined by job type. Figure 1 shows the results. For each subsample, the female coefficients from two regressions are presented: One regression that only controls for survey wave fixed effects (unconditional) and one regression controlling for the full set of covariates presented in column (4) of Table 2 (conditional). For the full regression results, see Table A5 in the appendix (in addition, Table A9 shows the results from a Kitagawa-Oaxaca-Blinder decomposition for the different job types). As can be seen, there is substantial heterogeneity: While there is no significant gap in jobs requiring previous qualification, the conditional gap between self-employed male and female students equals $18 \log$ points. For the two largest groups, student research assistants and the "jobbing" category, the conditional gap is 1.9 log points and 4.9 $\log$ points, respectively. The conditional gap in the jobbing category is thus 2.5 times larger. Since student research assistants are employed in public service, this result is consistent with previous research on differences in the gender pay gap between the public and the private sector. For Germany, Destatis (2020) finds that the unadjusted pay gap is $9 \%$ in the public sector and $22 \%$ in the private sector.

Besides the public-private dimension, this heterogeneity analysis also provides some tentative evidence in support of recent research into negotiating behavior and 
competitiveness as drivers of gender pay gaps (see Niederle 2017; Blau and Kahn 2017; Bertrand 2011 for reviews). We find that gaps in student employment are largest in private tutoring (6.2 log points) and self-employment (18 log points), which are likely to be the jobs with the largest scope for pay negotiations.

We repeat the same analysis on subsamples defined by field of study instead of job type, the results of which are presented in Fig. A2 and Table A20. The conditional pay gap is largest among students of natural sciences and engineering, whereas it is insignificant among students of human and veterinary medicine. However, the differences in the gender gaps between study fields are much less substantial than those between job types.

\subsection{Selection into work and certain kinds of jobs}

To better understand the interaction between gender and job types, we perform linear probability regressions ${ }^{9}$ of different binary employment variables on the gender dummy and our full set of control variables, excluding job types. Column (1) of Table 4 shows the results for a variable indicating employment in general. As mentioned in Sect. 2, in Germany, female students are more likely to work alongside their studies than male students. The positive and significant female coefficient in column (1) shows that this descriptive fact is robust to the introduction of extensive controls: female students are 4 percentage points more likely to work. Furthermore, there is substantial variation between fields of study, with students of medicine 17 percentage points less likely to work than students of the humanities.

Columns (2) and (3) present the results from linear probability regressions of dependent variables indicating employment in the two largest job type categories, respectively: student/research assistants in column (2) and "Jobbing" in column (3). These analyses are performed on the sample of working students also used in our main wage analysis. Together, these two columns provide more rigorous evidence for the descriptive gender differences in job types presented in Table 1. Female students are 3.6 percentage points less likely than male students to hold student/research assistant positions and 6.1 percentage points more likely than male students to work in jobs belonging to the "Jobbing" category. As we have documented, "Jobbing" carries a significant wage disadvantage compared to student/research assistant jobs, contributing to the unadjusted gender pay gap.

These results have potential implications for students' labor market outcomes beyond wage considerations. This could hold true especially for careers in academia: As student/research assistant positions enable students to gain research experience and build networks with professors and other researchers, these positions often pave the way for postgraduate and doctorate study. This comparatively small share of females in student/research assistant positions could therefore contribute to the "leaky pipeline" phenomenon, which describes the decline in the fraction of women along academic career paths in many disciplines (see, for example, Buckles (2019) for economics, Carrell et al. (2010) for STEM).

\footnotetext{
9 Probit regressions of the same specification generate very similar results, which can be found in Table A6 in the appendix.
} 


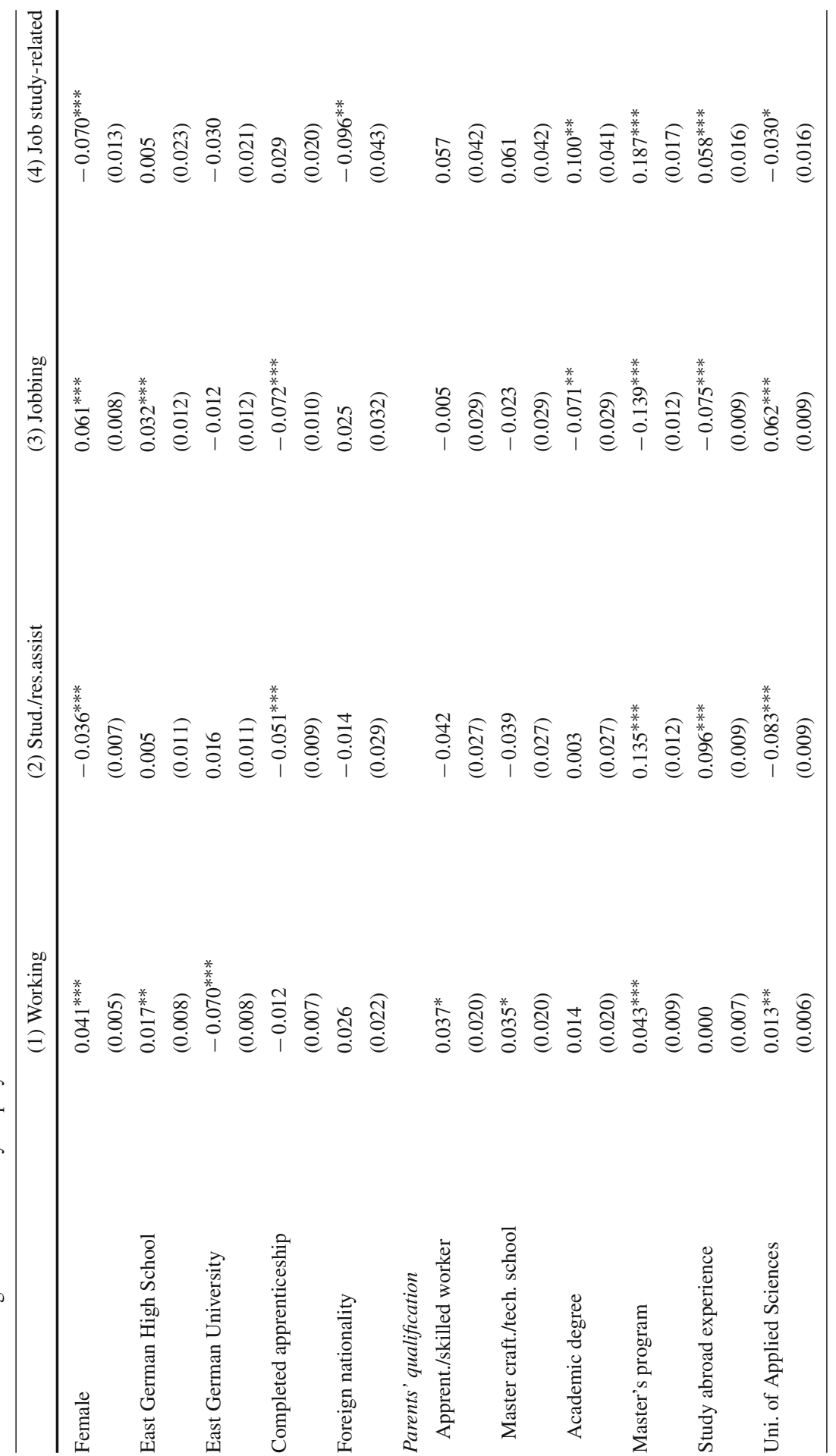




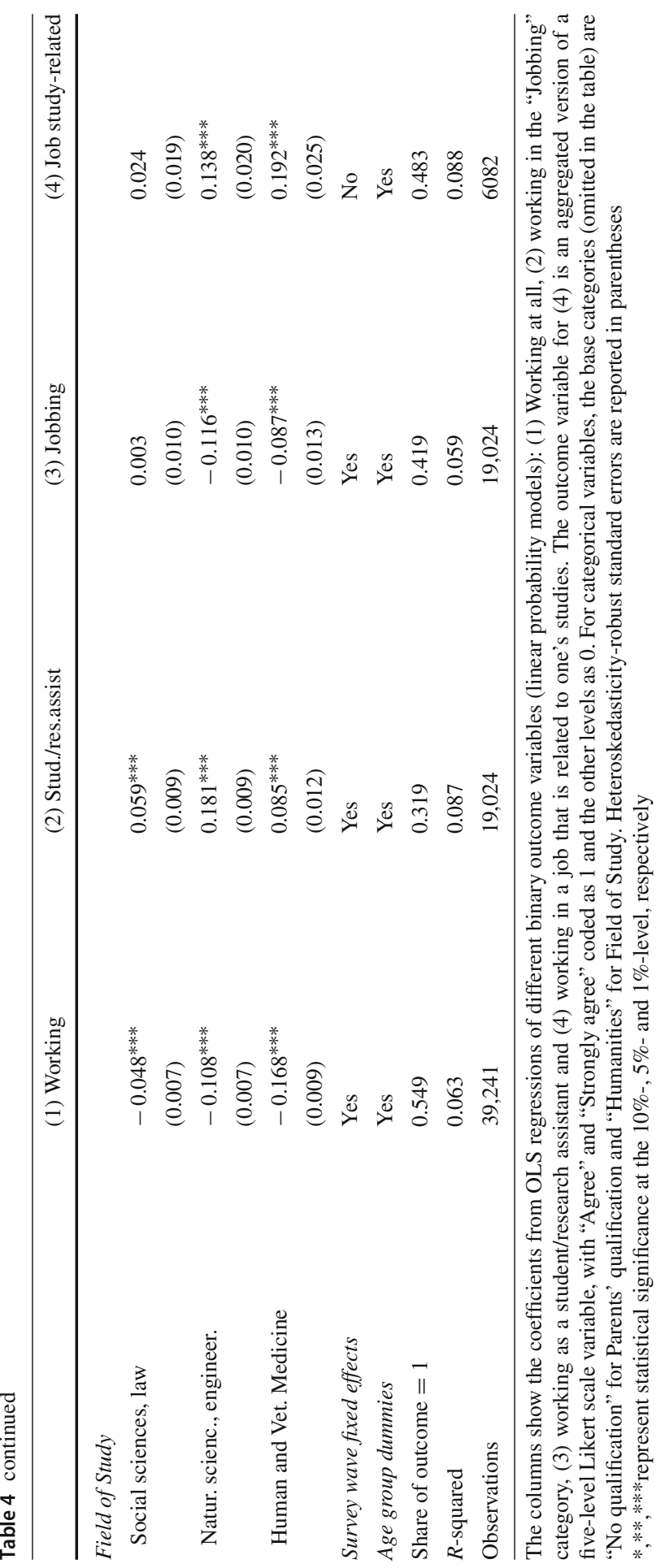


Column (4) shows the results of a related analysis. As discussed before, respondents in the 2016 wave were asked about the extent to which their job was related to their studies. A binarized version of this variable is the dependent variable of the regression presented in column (4). This analysis is performed on a sample of working students from the 2016 wave. The results show that female students are 7 percentage points less likely than male students to work in a job which is related to their studies. This goes beyond the results in columns (2) and (3) by extending to all job types, but leads to a similar stylized result: Female students are more likely than male students to work in jobs which require relatively unspecific skills. This probably provides female students with relatively smaller work experience gains. Any resulting gender gap in work experience could impact women's later career prospects.

Additionally, we estimate multinomial logit models of the selection into work and job types which allow for multiple outcomes in contrast to the binary analyses above. Tables A14 and A15 present average marginal effects from two multinomial logit models, where the former is performed on a sample of working and non-working students and includes non-working as well as the six job type categories as outcomes. The latter is performed on a sample of working students and includes only the six job types as outcomes. The results from these analyses on working/non-working and the two most common job types are very similar to those discussed above; the results regarding the remaining job types support the descriptive results discussed before.

To better understand how the documented gender differences in the selection into employment are explained by gender differences in other factors, we conduct a decomposition of the probit regressions presented in Table A6 (corresponding to Table 4) following the procedure by Yun (2004). This procedure decomposes the unconditional gender difference in the binary employment outcomes into an explained and an unexplained part, and details how each covariate contributes to each of these parts. The results can be found in Table A12: For the explained part, students' field of study is by far the single most important factor in explaining gender differences in working, working as a student/research assistant, working in the "Jobbing" category, and working in a job that is related to one's studies. Table 4 shows that field of study is significantly related to all four outcomes, so it is not surprising that gender differences in the choice of subject explain some of the differences in these outcomes. For example, students of natural sciences or engineering are significantly less likely to be employed, but, conditional on working, more likely to be employed as student/research assistants and in jobs related to their studies. Women are less likely to study natural sciences or engineering, which partly explains their higher probability to work and lower probability to work as student/research assistants or in jobs related to their studies, conditional on working. However, the unexplained parts of the gender differences in the four binary outcomes are very close to the "female" coefficients from the linear probability regressions, suggesting that significant fractions of the unconditional gender differences in employment and job types are not explained by field of study or similar factors.

Furthermore, we repeat the selection analyses with income from non-work sources as an additional covariate. From a theoretical perspective, non-work income appears as an obvious factor driving students' employment decisions. Tables A16 and A17 show the results from linear probability and probit regressions, respectively, corresponding to Tables 4 and A6. As expected, the propensity to work is strongly decreasing in non- 
work income. However, within the sample of working students, non-work income is positively associated with the probability of being a student/research assistant and negatively associated with the probability of working in the "Jobbing" category. This suggests that students with higher non-work incomes tend to work as student/research assistants, whereas those with lower non-work incomes select into "Jobbing." The results for the remaining covariates are very similar to those which do not include non-work income. Again, we provide multinomial logit estimations to complement the binary analyses, results can be found in Tables A18 and A19. However, as discussed in Sect. 4.1, endogeneity concerns regarding the non-work income variable lead us not to include it in our main results.

Finally, a potential concern about the wage analysis in Sect. 4.1 is selection bias due to gender differences in the selection into working. This is an important aspect in analyses of gender wage gaps in general labor markets, since women are generally less likely to be employed. As mentioned in Sect. 2 and shown above however, this does not apply to the German student labor market, where women are actually more likely to work than men. Nevertheless, we apply a standard Heckman (1979) procedure to correct for potential biases using three different specifications of the selection equation: Firstly, as shown in Table 2, the field of study is not significantly associated with wages, but significantly predicts employment as shown in Table 4 . Therefore, it may be a reasonable exclusion restriction for the Heckman procedure. Secondly, as discussed above, non-work income is negatively associated with employment probability and therefore provides another exclusion restriction. Thirdly, we use the combination of both variables and their interaction as exclusion restrictions in a third specification. Estimates from all three specifications are presented in the three columns of Table A11: The female coefficient is very close to our estimate in Table 2 in each case, and in none of the three models can the null hypothesis of independent equations be rejected. This suggests that our estimates are not substantially biased by sample selection.

\section{Conclusion}

While being well-documented for employees with completed education careers, gender pay gaps in student jobs have received little attention in the labor market literature. Since a growing proportion of university students is working alongside their studies, this omits an increasingly important part of workers' employment biographies. Using data from a large-scale student survey, we document a sizable pay gap between male and female university students in Germany. We find that female students earn about $6 \%$ less than male students on average. This unadjusted gap reduces to $4.1 \%$ when controlling for a large set of covariates including demographic information, study characteristics and employment variables. Results are robust to the inclusion of ability and personality controls, as well as to various sample restrictions. We find the most important factor in explaining gender wage gaps to be differences in the types of jobs male and female students hold: Male students are more often employed as student or research assistants or generally in jobs that are related to their studies, whereas female students more often work in jobs with less specific skill requirements, for example as waiters or office assistants. Beyond explaining wage differences, these findings are 
relevant to the literature on occupational differences between men and women and relate, for example, to the work of Ochsenfeld (2014) who shows that men choose more often majors which have higher-paid jobs after finishing studies. Additionally, the experiences in the student labor market potentially shape the future wage expectations and social constructions of young men and women, which could lead to even more wage inequality in the long run (Auspurg et al. 2017).

Our study provides at least three starting points for future research. First, our results suggest that gender pay gaps may stem from factors that even precede the pursuit of tertiary education. Further research is needed to understand at which point in workers' lives these differences emerge. Second, eliciting more nuanced occupational data among students could enable a detailed analysis of gender differences in job choice as a driver of pay gaps. For instance, future research may benefit from the linkage of the German National Education Panel Survey (NEPS) with administrative labor market data (NEPS-ADIAB). Third, it needs to be evaluated to what extent wage discrimination is driving gender wage gaps at this early stage. In future work, vignette study designs could help to disentangle whether the wage gap among university students is mainly driven by the supply side, i.e., via selection of female students into lower-paid positions, or also driven by labor demand, i.e., lower success probabilities of female students to get a well-paid job offer.

Acknowledgements We thank Vera Freundl, Lavinia Kinne, Aderonke Osikominu, Giannina Vaccaro and Andrea Weber for valuable discussions and suggestions.

Data and code availability All data are available from the research data center of the Germen Centre for Higher Education Research (DZHW), Hannover, Germany. Code will be made available from the authors.

Open Access This article is licensed under a Creative Commons Attribution 4.0 International License, which permits use, sharing, adaptation, distribution and reproduction in any medium or format, as long as you give appropriate credit to the original author(s) and the source, provide a link to the Creative Commons licence, and indicate if changes were made. The images or other third party material in this article are included in the article's Creative Commons licence, unless indicated otherwise in a credit line to the material. If material is not included in the article's Creative Commons licence and your intended use is not permitted by statutory regulation or exceeds the permitted use, you will need to obtain permission directly from the copyright holder. To view a copy of this licence, visit http://creativecommons.org/licenses/by/4.0/.

\section{A Appendix}

\section{A.1 Further information on the data}

Expanding on the discussion in Sect. 3, this section gives further details about the sample restrictions leading from 124,364 total observations across the five survey waves to our sample of 19,024 observations for the main analysis. Besides the "focus type" restriction, we further exclude students who were on leave ("vacation semester") or doing an internship at the time of the survey, because our focus is on student jobs pursued while actively studying. Students who did not earn their university entrance qualification in Germany are also excluded, because such students were only surveyed in two of the survey waves using different questionnaires. An additional sample restric- 


\begin{tabular}{|c|c|c|c|}
\hline & Men & Total & Women \\
\hline \multirow[t]{2}{*}{ All observations } & & 124,364 & \\
\hline & & $-0.76 \%$ & \\
\hline \multirow[t]{2}{*}{ Gender observed } & 53,740 & 123,418 & 69,678 \\
\hline & $-13.14 \%$ & $-13.05 \%$ & $-12.98 \%$ \\
\hline \multirow[t]{2}{*}{ Exclude interns, vacation, abitur abroad } & 46,681 & 107,313 & 60,632 \\
\hline & $-52.21 \%$ & $-51.27 \%$ & $-50.56 \%$ \\
\hline \multirow[t]{2}{*}{ Focus type } & 22,311 & 52,290 & 29,979 \\
\hline & $-4.68 \%$ & $-4.15 \%$ & $-3.75 \%$ \\
\hline \multirow[t]{2}{*}{ Employment status observed } & 21,266 & 50,122 & 28,856 \\
\hline & $-15.58 \%$ & $-16.21 \%$ & $-16.68 \%$ \\
\hline \multirow{2}{*}{ No more than one job } & 17,953 & 41,996 & 24,043 \\
\hline & $-4.56 \%$ & $-3.96 \%$ & $-3.50 \%$ \\
\hline \multirow[t]{2}{*}{ Socio-demographic variables observed } & 17,134 & 40,335 & 23,201 \\
\hline & $-2.62 \%$ & $-2.71 \%$ & $-2.78 \%$ \\
\hline \multirow[t]{2}{*}{ Student variables observed } & 16,685 & 39,241 & 22,556 \\
\hline & $-46.56 \%$ & $-45.07 \%$ & $-43.97 \%$ \\
\hline \multirow[t]{2}{*}{ Working } & 8,917 & 21,555 & 12,638 \\
\hline & $-0.71 \%$ & $-0.59 \%$ & $-0.51 \%$ \\
\hline Job type observed & 8,854 & 21,428 & 12,574 \\
\hline & $-12.24 \%$ & $-11.22 \%$ & $-10.50 \%$ \\
\hline Wage observed & 7,770 & 19,024 & 11,254 \\
\hline
\end{tabular}

Fig. A1 Observation numbers by stage of sample restriction

tion arises from a limitation in the 2003, 2006 and 2009 waves: Respondents were able to specify several jobs, but only one wage. Therefore, wages can only be linked to jobs for observations in which only one job was reported. This was improved upon in the 2012 and 2016 waves, but for our main analysis, we exclude all students with more than one job. Relaxing this in the 2012 and 2016 waves does not change the results significantly, as can be seen in Table A3, column (2). Furthermore, our sample for the wage analysis is obviously restricted to working students; the potential selection bias arising from the selection into working is discussed in Sect. 4.4. The remaining restrictions arise from missing or implausible data in the variables of interest, we deal with these observations using listwise deletion. Beyond those plausibility restrictions imposed by the publisher of the data set, we only impose one additional restriction on the hourly wage variable: Implausible wage values are particularly prevalent in the 2016 wave, which was the first wave to use internet-based questionnaires instead of a pen-and-paper format. This allowed for a considerable increase in the sample size and the number of observed variables, but also seems to have diminished response quality. The survey waves 2003 through 2012 restrict the wage variable to values 
below 100 Euros; for consistency, we apply the same restriction to the 2016 wave. To rule out biases from pooling methodologically different surveys, we add survey wave dummies throughout and also conduct the analysis separately for each wave, finding similar results (see Table A2). Figure A1 shows the effects of the sample restrictions on observation numbers, both for the total number of observations and broken down by gender. Missing data restrictions are depicted in a darker shade. Quantitatively most important are the restrictions on "focus type" and working students, followed by the exclusion of students with more than one job and those with missing wage data. Considering the reasonable gender balance in the missing data restrictions, bias through item non-response should be negligible.

Furthermore, Table 3 introduces several variables which may raise questions as to their coding and accuracy. Firstly, for our ability measure we use an aggregated version of High School GPA: German university entrance qualifications (most commonly the Abitur) are graded on a scale ranging from 1.0 (best possible grade) to 4.0 (worst passing grade). Our aggregate measure comprises four categories: Very good (1.0-1.5), Good (1.6-2.5), Satisfactory (2.6-3.5), Sufficient (3.6-4.0). Secondly, the variable "Job study-related" is based on a question asking respondents to report the extent to which their job was related to their studies in terms of content on a five-point Likert scale. Our binary measure codes 1, 2 and 3 as "Job not-study-related" and 4 and 5 as "Job study-related." Thirdly, self-efficacy is measured in the survey using the AKSU framework proposed by Beierlein et al. (2013), consisting of three five-point Likert items. We use the simple mean of the three items as our self-efficacy measure. Fourthly, to measure Big Five personality dimensions, the survey uses the BFI-10 framework proposed by Rammstedt et al. (2013). This comprises ten questions, two for each of the five personality dimensions, which are answered on a five-point Likert scale. Each dimension is measured by one positive and one negative item. For example, surveys include one item for agreeableness and one item for disagreeableness. We combine these measures by reversing the negative item and taking the simple mean of the two items for each dimension.

\section{A.2 Additional tables}

See Fig. A2 and Tables A1, A2, A3, A4, A5, A6, A7, A8, A9, A10, A11, A12, A13, A14, A15, A16, A17, A18, A19, A20. 


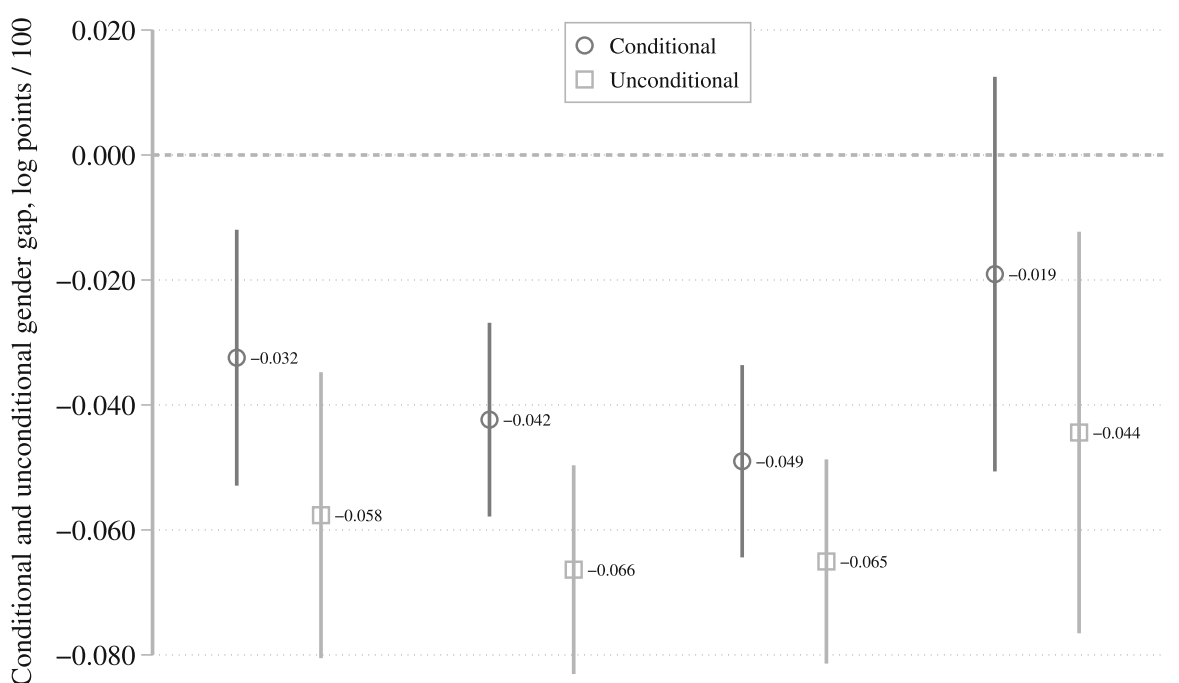

Humanities Soc. scienc., law Nat. scienc., engin. Hum. \& Vet. med.

$$
\mathrm{N}=5,307 \quad \mathrm{~N}=5,785 \quad \mathrm{~N}=6,027 \quad \mathrm{~N}=1,905
$$

Fig. A2 The gender pay gap across study fields. Notes The figure presents point estimates and $95 \%$-level confidence intervals for the female coefficient $\beta$ from separate wage regressions of the form described in equation (1) in the respective study field subsample. The coefficients labeled "conditional" stem from regressions using the full set of controls (see Table A20 for full results), the coefficients labeled "uncon-

\begin{tabular}{|c|c|c|c|c|c|}
\hline \multirow[t]{2}{*}{ Variable } & \multirow[t]{2}{*}{ Overall mean } & \multicolumn{2}{|c|}{ Group means } & \multirow[t]{2}{*}{ Difference } & \multirow[t]{2}{*}{$P$ value } \\
\hline & & Men & Women & & \\
\hline Net hourly wage (euros) & $\begin{array}{l}9.765 \\
(4.988)\end{array}$ & $\begin{array}{l}10.221 \\
(5.182)\end{array}$ & $\begin{array}{l}9.451 \\
(4.825)\end{array}$ & 0.770 & $0.000 * * *$ \\
\hline \multicolumn{6}{|l|}{ Wave } \\
\hline 2003 wave & $\begin{array}{l}0.202 \\
(0.402)\end{array}$ & $\begin{array}{l}0.206 \\
(0.404)\end{array}$ & $\begin{array}{l}0.200 \\
(0.400)\end{array}$ & 0.006 & 0.301 \\
\hline 2006 wave & $\begin{array}{l}0.160 \\
(0.366)\end{array}$ & $\begin{array}{l}0.149 \\
(0.356)\end{array}$ & $\begin{array}{l}0.167 \\
(0.373)\end{array}$ & -0.018 & $0.001 * * *$ \\
\hline 2009 wave & $\begin{array}{l}0.172 \\
(0.377)\end{array}$ & $\begin{array}{l}0.165 \\
(0.371)\end{array}$ & $\begin{array}{l}0.176 \\
(0.381)\end{array}$ & -0.011 & $0.041 * *$ \\
\hline 2012 wave & $\begin{array}{l}0.145 \\
(0.353)\end{array}$ & $\begin{array}{l}0.135 \\
(0.342)\end{array}$ & $\begin{array}{l}0.153 \\
(0.360)\end{array}$ & -0.018 & $0.001 * * *$ \\
\hline 2016 wave & $\begin{array}{l}0.321 \\
(0.467)\end{array}$ & $\begin{array}{l}0.345 \\
(0.475)\end{array}$ & $\begin{array}{l}0.304 \\
(0.460)\end{array}$ & 0.041 & $0.000 * * *$ \\
\hline \multicolumn{6}{|l|}{ Age } \\
\hline Under 20 & $\begin{array}{l}0.025 \\
(0.155)\end{array}$ & $\begin{array}{l}0.016 \\
(0.126)\end{array}$ & $\begin{array}{l}0.030 \\
(0.171)\end{array}$ & -0.014 & $0.000 * * *$ \\
\hline
\end{tabular}
ditional" stem from regressions that only control for survey wave fixed effects. Confidence intervals are computed using heteroskedasticity-robust standard errors

Table A1 Descriptive statistics for all variables in the main specification 
Table A1 continued

\begin{tabular}{|c|c|c|c|c|c|}
\hline \multirow[t]{2}{*}{ Variable } & \multirow[t]{2}{*}{ Overall mean } & \multicolumn{2}{|c|}{ Group means } & \multirow[t]{2}{*}{ Difference } & \multirow[t]{2}{*}{$P$ value } \\
\hline & & Men & Women & & \\
\hline $20-22$ & $\begin{array}{l}0.332 \\
(0.471)\end{array}$ & $\begin{array}{l}0.261 \\
(0.439)\end{array}$ & $\begin{array}{l}0.381 \\
(0.486)\end{array}$ & -0.120 & $0.000 * * *$ \\
\hline $23-25$ & $\begin{array}{l}0.413 \\
(0.492)\end{array}$ & $\begin{array}{l}0.427 \\
(0.495)\end{array}$ & $\begin{array}{l}0.404 \\
(0.491)\end{array}$ & 0.023 & $0.002 * * *$ \\
\hline $26-30$ & $\begin{array}{l}0.197 \\
(0.398)\end{array}$ & $\begin{array}{l}0.250 \\
(0.433)\end{array}$ & $\begin{array}{l}0.160 \\
(0.367)\end{array}$ & 0.090 & $0.000^{* * *}$ \\
\hline Over 30 & $\begin{array}{l}0.033 \\
(0.180)\end{array}$ & $\begin{array}{l}0.046 \\
(0.209)\end{array}$ & $\begin{array}{l}0.025 \\
(0.156)\end{array}$ & 0.021 & $0.000 * * *$ \\
\hline East German High School & $\begin{array}{l}0.184 \\
(0.388)\end{array}$ & $\begin{array}{l}0.174 \\
(0.379)\end{array}$ & $\begin{array}{l}0.191 \\
(0.393)\end{array}$ & -0.017 & $0.003 * * *$ \\
\hline East German University & $\begin{array}{l}0.196 \\
(0.397)\end{array}$ & $\begin{array}{l}0.195 \\
(0.397)\end{array}$ & $\begin{array}{l}0.196 \\
(0.397)\end{array}$ & -0.001 & 0.887 \\
\hline Completed apprenticeship & $\begin{array}{l}0.192 \\
(0.394)\end{array}$ & $\begin{array}{l}0.213 \\
(0.409)\end{array}$ & $\begin{array}{l}0.178 \\
(0.383)\end{array}$ & 0.035 & $0.000 * * *$ \\
\hline Foreign nationality & $\begin{array}{l}0.012 \\
(0.109)\end{array}$ & $\begin{array}{l}0.012 \\
(0.110)\end{array}$ & $\begin{array}{l}0.012 \\
(0.108)\end{array}$ & 0.001 & 0.738 \\
\hline Masters program & $\begin{array}{l}0.118 \\
(0.323)\end{array}$ & $\begin{array}{l}0.138 \\
(0.345)\end{array}$ & $\begin{array}{l}0.105 \\
(0.306)\end{array}$ & 0.034 & $0.000^{* * *}$ \\
\hline Uni. of Applied Sciences & $\begin{array}{l}0.213 \\
(0.409)\end{array}$ & $\begin{array}{l}0.244 \\
(0.430)\end{array}$ & $\begin{array}{l}0.191 \\
(0.393)\end{array}$ & 0.053 & $0.000 * * *$ \\
\hline Study abroad experience & $\begin{array}{l}0.211 \\
(0.408)\end{array}$ & $\begin{array}{l}0.178 \\
(0.383)\end{array}$ & $\begin{array}{l}0.233 \\
(0.423)\end{array}$ & -0.055 & $0.000^{* * *}$ \\
\hline \multicolumn{6}{|l|}{ Parents' education } \\
\hline No qualification & $\begin{array}{l}0.016 \\
(0.124)\end{array}$ & $\begin{array}{l}0.014 \\
(0.118)\end{array}$ & $\begin{array}{l}0.017 \\
(0.127)\end{array}$ & -0.002 & 0.170 \\
\hline Apprent./skilled worker & $\begin{array}{l}0.249 \\
(0.433)\end{array}$ & $\begin{array}{l}0.253 \\
(0.435)\end{array}$ & $\begin{array}{l}0.247 \\
(0.431)\end{array}$ & 0.007 & 0.300 \\
\hline Master craft./tech. school & $\begin{array}{l}0.199 \\
(0.399)\end{array}$ & $\begin{array}{l}0.197 \\
(0.397)\end{array}$ & $\begin{array}{l}0.200 \\
(0.400)\end{array}$ & -0.003 & 0.563 \\
\hline Academic degree & $\begin{array}{l}0.537 \\
(0.499)\end{array}$ & $\begin{array}{l}0.536 \\
(0.499)\end{array}$ & $\begin{array}{l}0.537 \\
(0.499)\end{array}$ & -0.001 & 0.923 \\
\hline \multicolumn{6}{|l|}{ Study field } \\
\hline Humanities & $\begin{array}{l}0.279 \\
(0.449)\end{array}$ & $\begin{array}{l}0.161 \\
(0.367)\end{array}$ & $\begin{array}{l}0.361 \\
(0.480)\end{array}$ & -0.200 & $0.000 * * *$ \\
\hline Social sciences, law & $\begin{array}{l}0.304 \\
(0.460)\end{array}$ & $\begin{array}{l}0.288 \\
(0.453)\end{array}$ & $\begin{array}{l}0.315 \\
(0.465)\end{array}$ & -0.028 & $0.000 * * *$ \\
\hline
\end{tabular}


Table A1 continued

\begin{tabular}{|c|c|c|c|c|c|}
\hline \multirow[t]{2}{*}{ Variable } & \multirow[t]{2}{*}{ Overall mean } & \multicolumn{2}{|c|}{ Group means } & \multirow[t]{2}{*}{ Difference } & \multirow[t]{2}{*}{$P$ value } \\
\hline & & Men & Women & & \\
\hline Natur. scienc., engineer. & $\begin{array}{l}0.317 \\
(0.465)\end{array}$ & $\begin{array}{l}0.475 \\
(0.499)\end{array}$ & $\begin{array}{l}0.208 \\
(0.406)\end{array}$ & 0.267 & $0.000 * * *$ \\
\hline Human and Vet. Medicine & $\begin{array}{l}0.100 \\
(0.300)\end{array}$ & $\begin{array}{l}0.077 \\
(0.266)\end{array}$ & $\begin{array}{l}0.116 \\
(0.321)\end{array}$ & -0.040 & $0.000 * * *$ \\
\hline \multicolumn{6}{|l|}{ Job type } \\
\hline Student/research assistant & $\begin{array}{l}0.319 \\
(0.466)\end{array}$ & $\begin{array}{l}0.367 \\
(0.482)\end{array}$ & $\begin{array}{l}0.286 \\
(0.452)\end{array}$ & 0.081 & $0.000 * * *$ \\
\hline Jobbing & $\begin{array}{l}0.419 \\
(0.493)\end{array}$ & $\begin{array}{l}0.361 \\
(0.480)\end{array}$ & $\begin{array}{l}0.459 \\
(0.498)\end{array}$ & -0.098 & $0.000 * * *$ \\
\hline Private tutoring & $\begin{array}{l}0.054 \\
(0.226)\end{array}$ & $\begin{array}{l}0.039 \\
(0.195)\end{array}$ & $\begin{array}{l}0.064 \\
(0.244)\end{array}$ & -0.024 & $0.000 * * *$ \\
\hline Job requiring qualification & $\begin{array}{l}0.062 \\
(0.241)\end{array}$ & $\begin{array}{l}0.066 \\
(0.248)\end{array}$ & $\begin{array}{l}0.059 \\
(0.235)\end{array}$ & 0.007 & $0.045^{* *}$ \\
\hline Self-employed work & $\begin{array}{l}0.048 \\
(0.214)\end{array}$ & $\begin{array}{l}0.063 \\
(0.244)\end{array}$ & $\begin{array}{l}0.038 \\
(0.190)\end{array}$ & 0.026 & $0.000 * * *$ \\
\hline Other & $\begin{array}{l}0.098 \\
(0.298)\end{array}$ & $\begin{array}{l}0.104 \\
(0.305)\end{array}$ & $\begin{array}{l}0.095 \\
(0.293)\end{array}$ & 0.009 & $0.041^{* *}$ \\
\hline Observations & 19,024 & 7770 & 11,254 & & \\
\hline
\end{tabular}

The table presents descriptive statistics on all variables in the main specification, both for the full sample and split by gender. Standard deviations are reported in parentheses. $\mathrm{P}$ values derive from a test for equality of mean in the case of the wage variable and Pearson's $\chi^{2}$ tests for the remaining categorical variables. All variables except net hourly wage are indicator variables, their means therefore represent shares of the respective sample

$*, * *, * * *$ represent statistical significance at the $10 \%-, 5 \%$ - and $1 \%$-level, respectively 


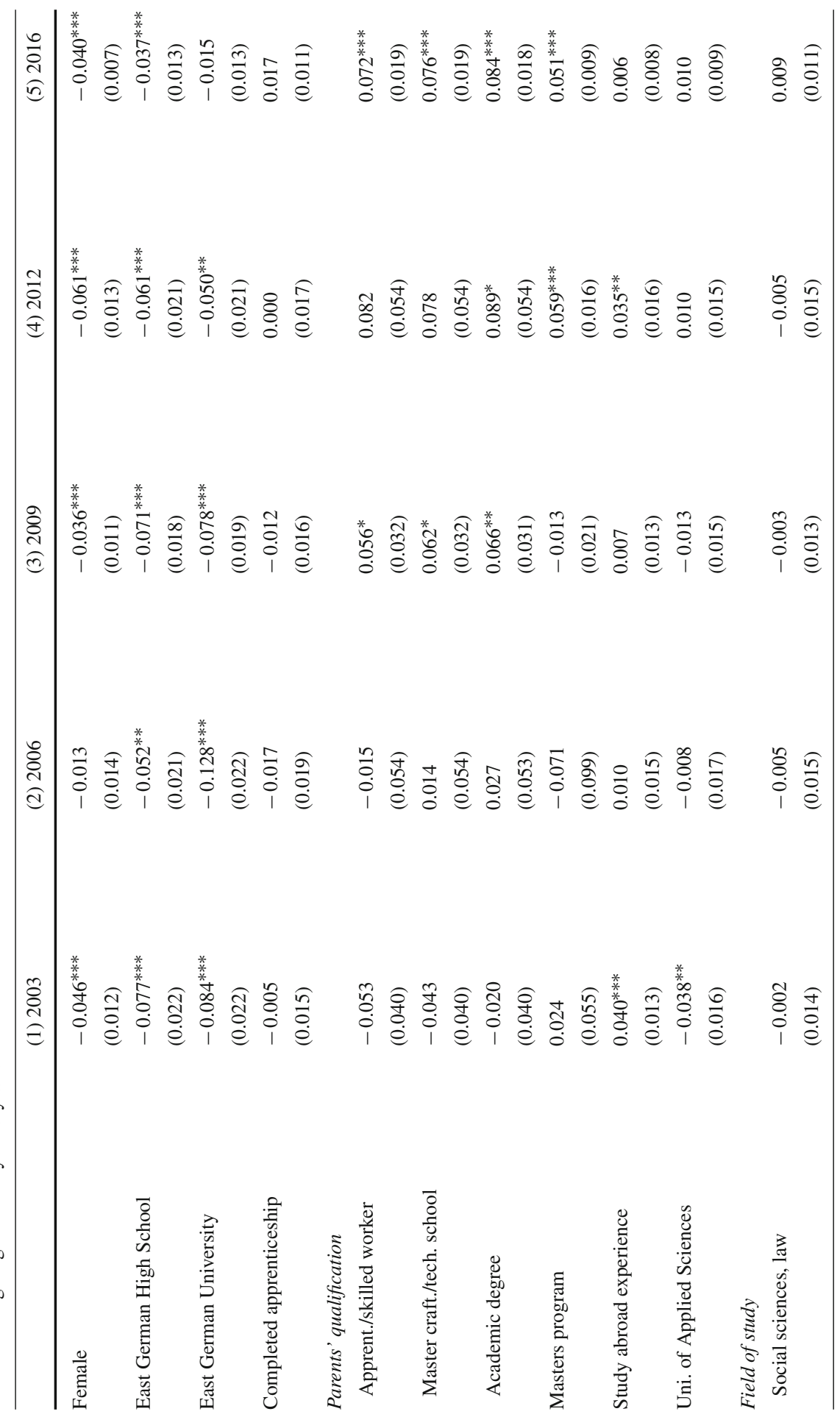




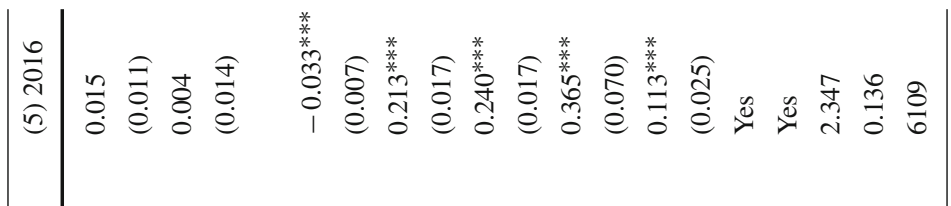

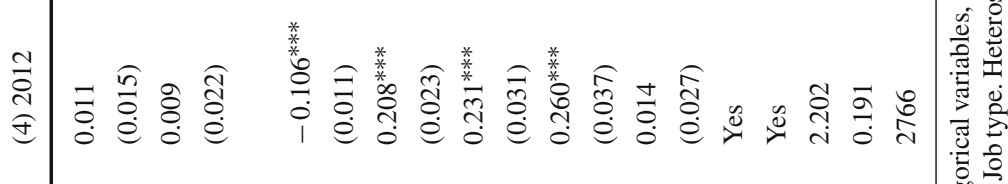

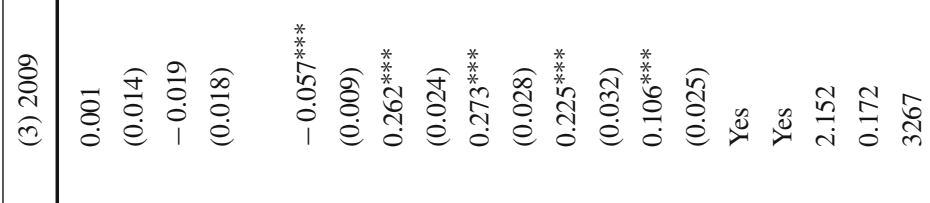

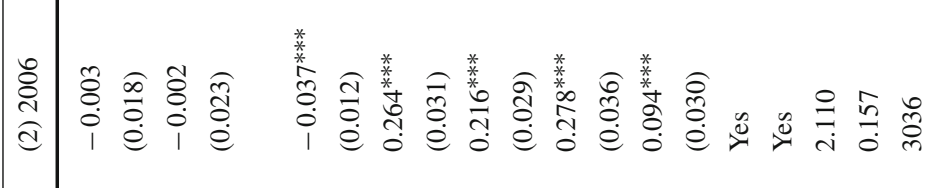

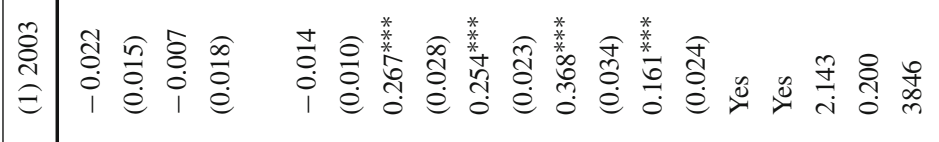

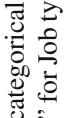

$$
\begin{aligned}
& \text { 嗼 } \\
& \text { गे } \\
& \text { ह } \\
& \text { 忥 } \\
& \text { 运 }
\end{aligned}
$$

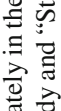

$$
\begin{aligned}
& \text { 출 } \\
& \text { 눙 } \\
& \text { 这 }
\end{aligned}
$$

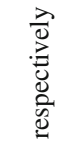

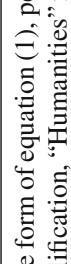

$$
\begin{aligned}
& \text { 总 } \\
& \begin{array}{lll}
0 & 0 \\
0 & 0 & 0 \\
0 & 0 & 0 \\
0 & 0 \\
0 & 0 & 0 \\
0 & 0 & 0
\end{array}
\end{aligned}
$$

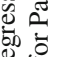

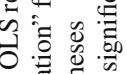

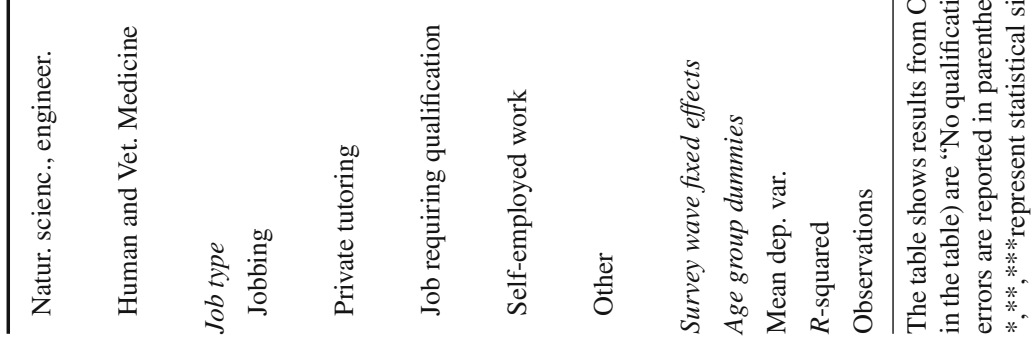


Table A3 Robustness to sample restrictions

\begin{tabular}{|c|c|c|c|}
\hline & (1) & (2) & (3) \\
\hline Female & $\begin{array}{l}-0.036^{* * *} \\
(0.004)\end{array}$ & $\begin{array}{l}-0.036^{* * *} \\
(0.004)\end{array}$ & $\begin{array}{l}-0.047^{* * *} \\
(0.011)\end{array}$ \\
\hline East German High School & $\begin{array}{l}-0.070^{* * *} \\
(0.007)\end{array}$ & $\begin{array}{l}-0.031^{* * *} \\
(0.008)\end{array}$ & $\begin{array}{l}-0.067^{* * *} \\
(0.019)\end{array}$ \\
\hline East German University & $\begin{array}{l}-0.063^{* * *} \\
(0.007)\end{array}$ & $\begin{array}{l}-0.040^{* * *} \\
(0.008)\end{array}$ & $\begin{array}{l}-0.090^{* * *} \\
(0.019)\end{array}$ \\
\hline Completed apprenticeship & $\begin{array}{l}-0.012^{* *} \\
(0.005)\end{array}$ & $\begin{array}{l}-0.011^{*} \\
(0.006)\end{array}$ & $\begin{array}{l}0.006 \\
(0.017)\end{array}$ \\
\hline Foreign nationality & $\begin{array}{l}-0.010 \\
(0.012)\end{array}$ & $\begin{array}{l}-0.006 \\
(0.013)\end{array}$ & $\begin{array}{l}-0.016 \\
(0.035)\end{array}$ \\
\hline \multicolumn{4}{|l|}{ Parents' qualification } \\
\hline Apprent./skilled worker & $\begin{array}{l}0.019^{*} \\
(0.011)\end{array}$ & $\begin{array}{l}0.046^{* * *} \\
(0.012)\end{array}$ & $\begin{array}{l}-0.002 \\
(0.037)\end{array}$ \\
\hline Master craft./tech. school & $\begin{array}{l}0.021^{*} \\
(0.011)\end{array}$ & $\begin{array}{l}0.046^{* * *} \\
(0.012)\end{array}$ & $\begin{array}{l}-0.003 \\
(0.037)\end{array}$ \\
\hline Academic degree & $\begin{array}{l}0.036^{* * *} \\
(0.011)\end{array}$ & $\begin{array}{l}0.058^{* * *} \\
(0.012)\end{array}$ & $\begin{array}{l}0.018 \\
(0.036)\end{array}$ \\
\hline Masters program & $\begin{array}{l}0.039 * * * \\
(0.005)\end{array}$ & $\begin{array}{l}0.037^{* * *} \\
(0.005)\end{array}$ & $\begin{array}{l}-0.001 \\
(0.018)\end{array}$ \\
\hline Study abroad experience & $\begin{array}{l}0.022^{* * *} \\
(0.004)\end{array}$ & $\begin{array}{l}0.011^{* *} \\
(0.005)\end{array}$ & $\begin{array}{l}0.049 * * * \\
(0.013)\end{array}$ \\
\hline Uni. of Applied Sciences & $\begin{array}{l}-0.020^{* * *} \\
(0.004)\end{array}$ & $\begin{array}{l}-0.003 \\
(0.005)\end{array}$ & $\begin{array}{l}-0.029^{* *} \\
(0.014)\end{array}$ \\
\hline \multicolumn{4}{|l|}{ Field of Study } \\
\hline Social sciences, law & $\begin{array}{l}-0.004 \\
(0.005)\end{array}$ & $\begin{array}{l}-0.007 \\
(0.006)\end{array}$ & $\begin{array}{l}-0.040^{* * *} \\
(0.014)\end{array}$ \\
\hline Natur. scienc., engineer. & $\begin{array}{l}-0.008^{*} \\
(0.005)\end{array}$ & $\begin{array}{l}0.001 \\
(0.006)\end{array}$ & $\begin{array}{l}-0.026^{*} \\
(0.015)\end{array}$ \\
\hline Human and Vet. Medicine & $\begin{array}{l}-0.005 \\
(0.006)\end{array}$ & $\begin{array}{l}-0.008 \\
(0.007)\end{array}$ & $\begin{array}{l}-0.040^{* *} \\
(0.017)\end{array}$ \\
\hline \multicolumn{4}{|l|}{ Job type } \\
\hline Jobbing & $\begin{array}{l}-0.058^{* * *} \\
(0.003)\end{array}$ & $\begin{array}{l}-0.052^{* * *} \\
(0.004)\end{array}$ & $\begin{array}{l}0.017^{*} \\
(0.010)\end{array}$ \\
\hline Private tutoring & $\begin{array}{l}0.216^{* * *} \\
(0.007)\end{array}$ & $\begin{array}{l}0.206^{* * *} \\
(0.009)\end{array}$ & $\begin{array}{l}0.268^{* * *} \\
(0.016)\end{array}$ \\
\hline Job requiring qualification & $\begin{array}{l}0.253^{* * *} \\
(0.007)\end{array}$ & $\begin{array}{l}0.269^{* * *} \\
(0.009)\end{array}$ & $\begin{array}{l}0.288^{* * *} \\
(0.029)\end{array}$ \\
\hline Self-employed work & $\begin{array}{l}0.325^{* * *} \\
(0.013)\end{array}$ & $\begin{array}{l}0.348^{* * *} \\
(0.023)\end{array}$ & $\begin{array}{l}0.328^{* * *} \\
(0.031)\end{array}$ \\
\hline
\end{tabular}


Table A3 continued

\begin{tabular}{llll}
\hline & $(1)$ & $(2)$ & $(3)$ \\
\hline Other & $0.079^{* * *}$ & $0.065^{* * *}$ & $0.130^{* * *}$ \\
& $(0.008)$ & $(0.012)$ & $(0.023)$ \\
Survey wave fixed effects & Yes & Yes & Yes \\
Age group dummies & Yes & Yes & Yes \\
Mean dep. var. & 2.240 & 2.325 & 2.207 \\
$R$-squared & 0.234 & 0.190 & 0.172 \\
Observations & 37,774 & 24,337 & 5094 \\
\hline
\end{tabular}

The table shows results from the main wage regression (equation (1)) performed in different samples. In column (1), the "focus type" restriction is relaxed, including students who do not satisfy the conditions mentioned in Sect. 3. Column (2) relaxes the restriction excluding students with more than one job. For the reasons mentioned in Sect. 3, this is only possible in the 2012 and 2016 waves, the other waves are not represented here. Column (3) shows the results of restricting the sample to those students who work five hours or less per week. For categorical variables, the base categories (omitted in the table) are "No qualification" for Parents' qualification, "Humanities" for Field of Study and "Student/research assistant" for Job type. Heteroskedasticity-robust standard errors are reported in parentheses

$*, * *, * * *$ represent statistical significance at the $10 \%-, 5 \%$ - and $1 \%$-level, respectively

Table A4 Wage regression including work hours and income

Female

East German High School

East German University

Completed apprenticeship

Foreign nationality

Parents' qualification

Apprent./skilled worker

Master craft./tech. school 
Table A4 continued

Study abroad experience

Uni. of Applied Sciences

Field of Study

Social sciences, law

Natur. scienc., engineer.

Human and Vet. Medicine

Job type

Jobbing

Private tutoring

Job requiring qualification

Self-employed work

\section{Other}

Log work hours per week

Log income excluding work income

Survey wave fixed effects

Yes

Age group dummies

Yes

Mean dep. var.

R-squared

Observations

The table shows results from an OLS regression of the form described in equation (1), where logarithmized work hours per week and logarithmized income excluding work income have been added to the main regression presented in Table 2. For categorical variables, the base categories (omitted in the table) are "No qualification" for Parents' qualification, "Humanities" for Field of Study and "Student/research assistant" for Job type. Heteroskedasticity-robust standard errors are reported in parentheses $*, * *, * * *$ represent statistical significance at the $10 \%-, 5 \%-$ and $1 \%$-level, respectively 


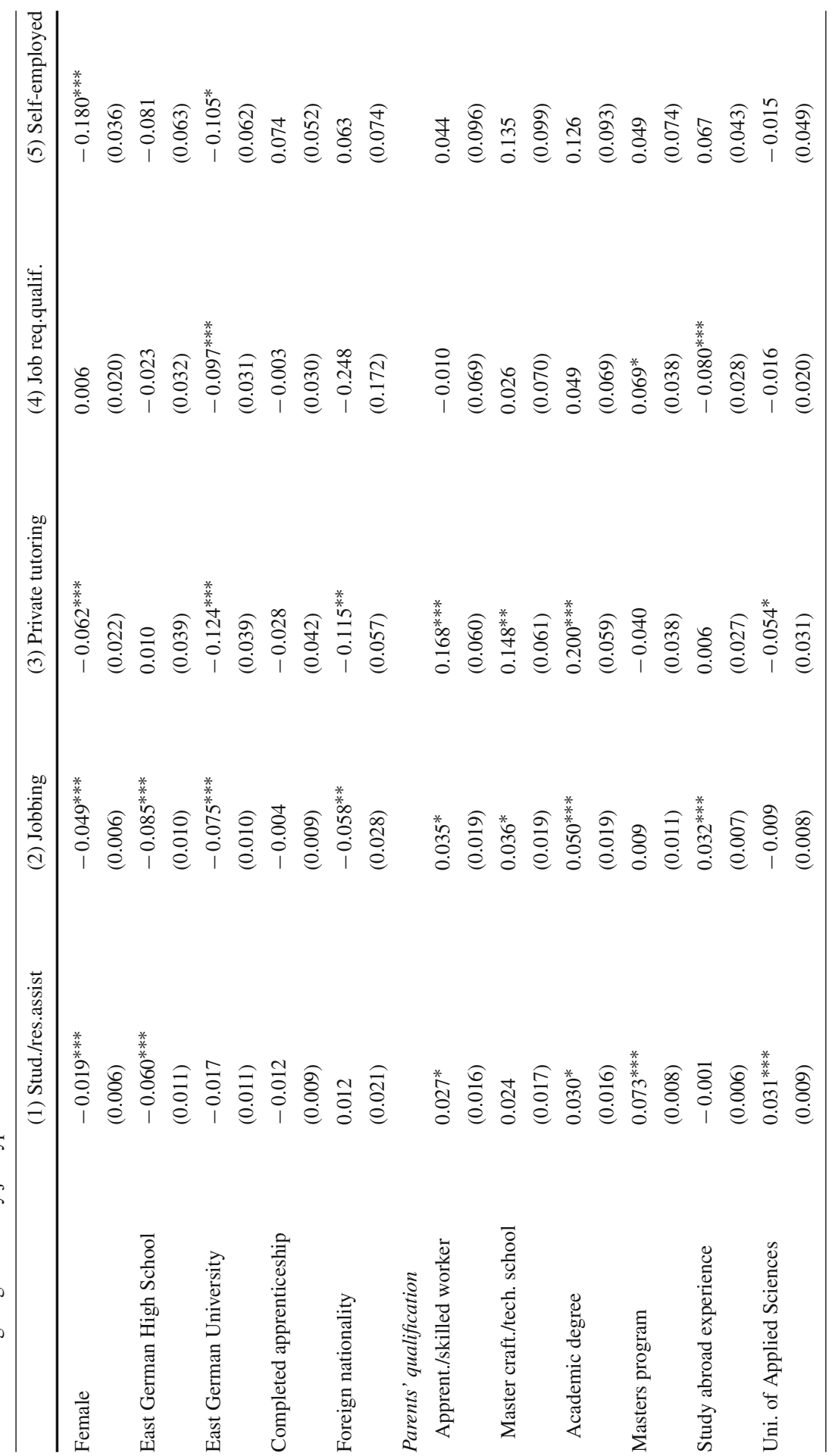




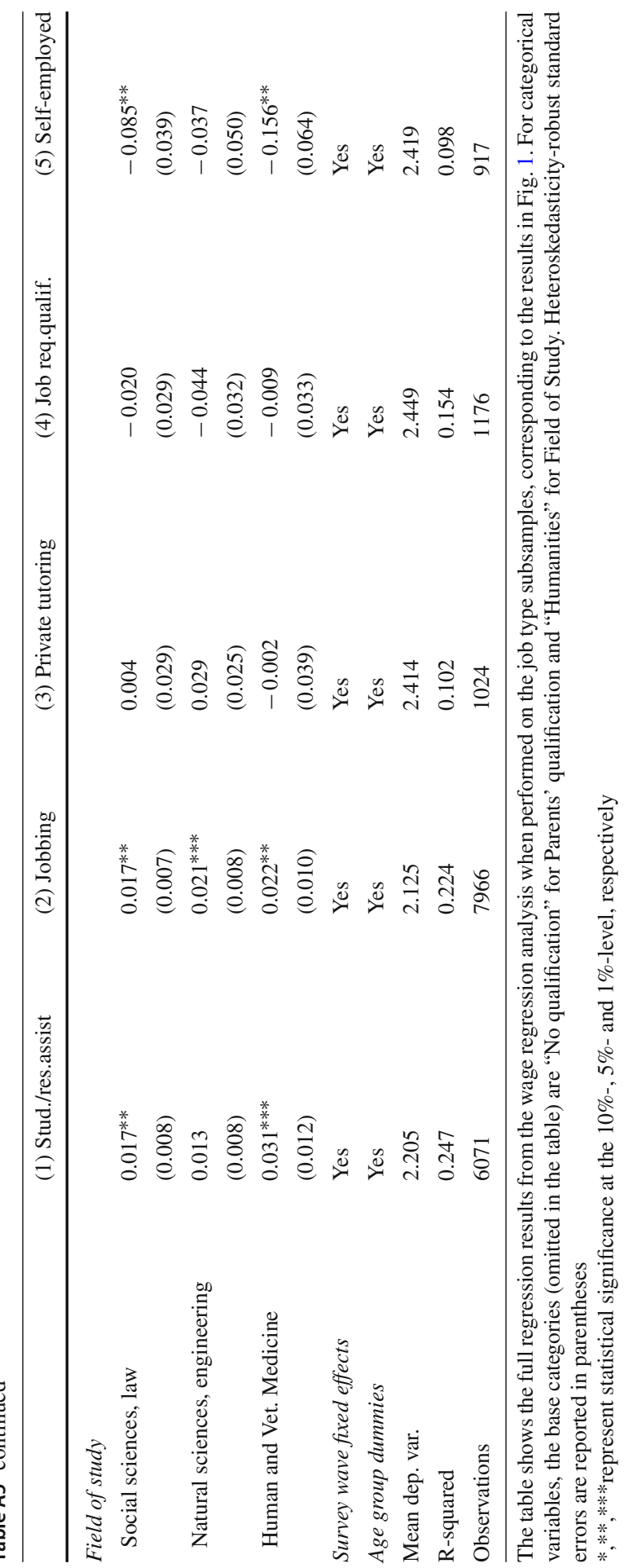




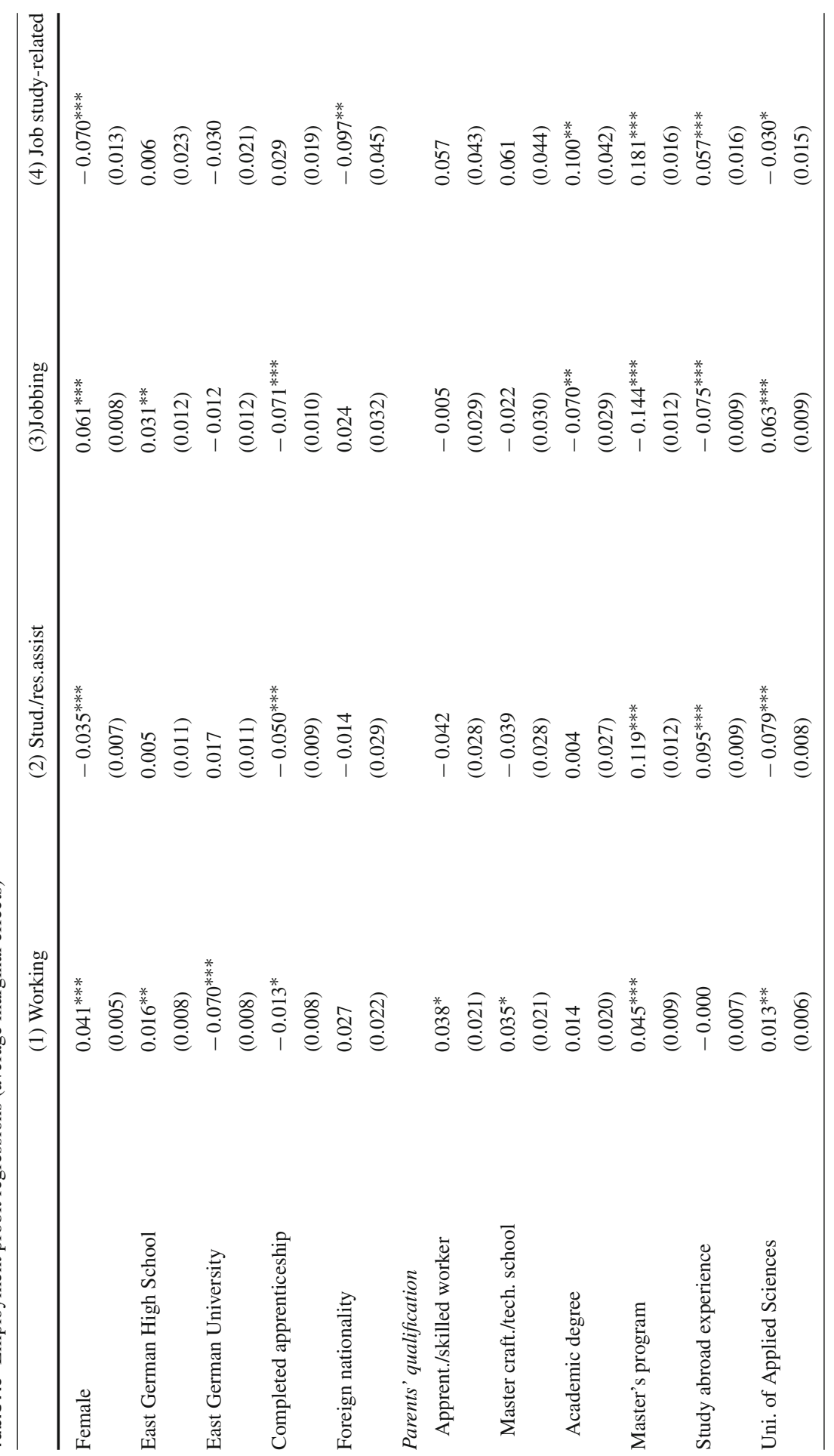




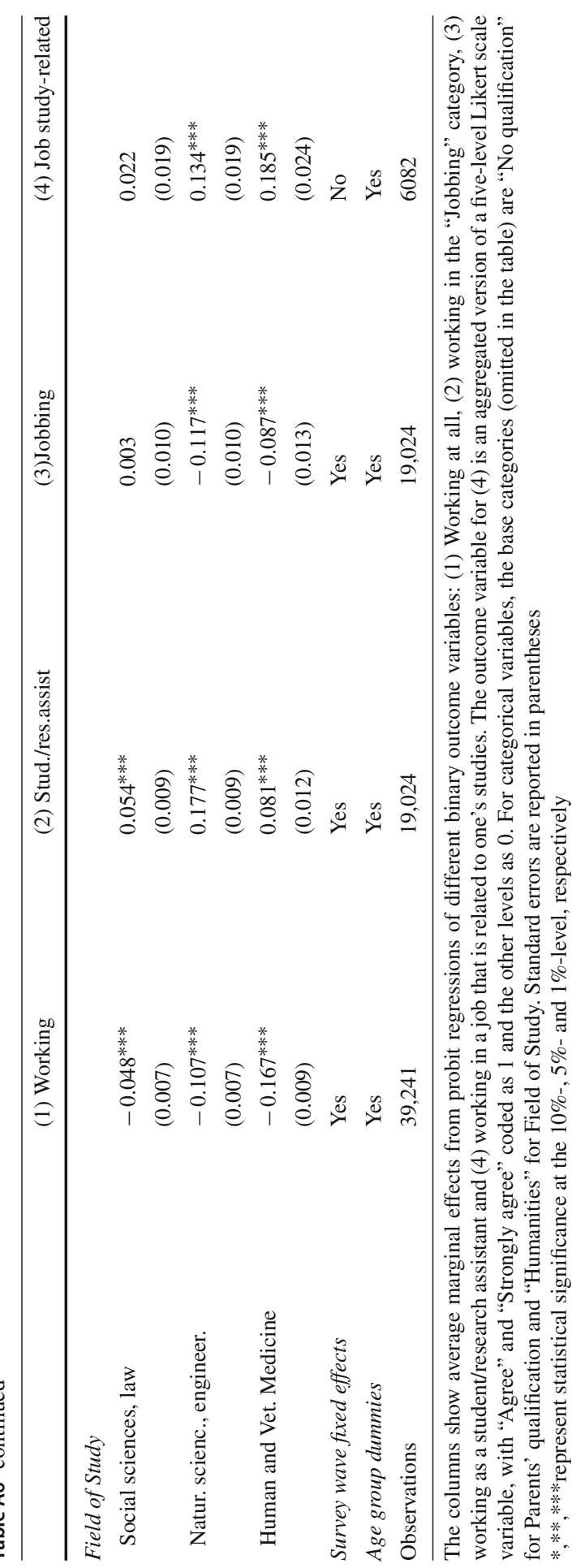


Table A7 Kitagawa-Oaxaca-Blinder wage decomposition (main specification)

\begin{tabular}{|c|c|c|}
\hline & Estimate & Standard error \\
\hline \multicolumn{3}{|l|}{ Aggregate decomposition } \\
\hline Mean males & $2.253^{* * *}$ & $(0.004)$ \\
\hline Mean females & $2.186^{* * *}$ & $(0.003)$ \\
\hline Difference & $0.067^{* * *}$ & $(0.005)$ \\
\hline Explained part & $0.027^{* * *}$ & $(0.003)$ \\
\hline Unexplained part & $0.041^{* * *}$ & $(0.005)$ \\
\hline \multicolumn{3}{|c|}{ Contribution of variables to explained part } \\
\hline Survey wave fixed effects & $0.008^{* * *}$ & $(0.001)$ \\
\hline Age group dummies & $0.008^{* * *}$ & $(0.001)$ \\
\hline East German High School & $0.001^{* * *}$ & $(0.000)$ \\
\hline East German University & 0.000 & $(0.000)$ \\
\hline Completed apprenticeship & -0.000 & $(0.000)$ \\
\hline Foreign nationality & -0.000 & $(0.000)$ \\
\hline Parents' qualification & 0.000 & $(0.000)$ \\
\hline Master's program & $0.001^{* * *}$ & $(0.000)$ \\
\hline Study abroad experience & $-0.001^{* * *}$ & $(0.000)$ \\
\hline University of Applied Sciences & -0.000 & $(0.000)$ \\
\hline Field of study & 0.000 & $(0.002)$ \\
\hline Job type & $0.009^{* * *}$ & $(0.002)$ \\
\hline \multicolumn{3}{|c|}{ Contribution of variables to unexplained part } \\
\hline Survey wave fixed effects & 0.001 & $(0.001)$ \\
\hline Age group dummies & -0.008 & $(0.007)$ \\
\hline East German High School & -0.003 & $(0.006)$ \\
\hline East German University & -0.000 & $(0.005)$ \\
\hline Completed apprenticeship & -0.005 & $(0.004)$ \\
\hline Foreign nationality & -0.003 & $(0.018)$ \\
\hline Parents' qualification & 0.002 & $(0.007)$ \\
\hline Master's program & 0.000 & $(0.005)$ \\
\hline Study abroad experience & 0.000 & $(0.003)$ \\
\hline University of Applied Sciences & 0.001 & $(0.003)$ \\
\hline Field of study & 0.003 & $(0.003)$ \\
\hline Job type & $-0.012^{* *}$ & $(0.006)$ \\
\hline Constant & $0.065^{* * *}$ & $(0.024)$ \\
\hline Observations & 19,024 & \\
\hline
\end{tabular}

The table shows results from a Kitagawa-Oaxaca-Blinder wage decomposition, as implemented by Jann (2008). The pooled coefficient vector is used as the reference. Heteroskedasticity-robust standard errors are reported in the second column in parentheses

$*, * *, * * *$ represent statistical significance at the $10 \%-, 5 \%$ - and $1 \%$-level, respectively 
Table A8 Kitagawa-Oaxaca-Blinder wage decomposition with ability and personality controls

\begin{tabular}{|c|c|c|}
\hline & Estimate & Standard error \\
\hline \multicolumn{3}{|l|}{ Aggregate decomposition } \\
\hline Mean males & $2.390^{* * *}$ & $(0.009)$ \\
\hline Mean females & $2.326^{* * *}$ & $(0.007)$ \\
\hline Difference & $0.064^{* * *}$ & $(0.011)$ \\
\hline Explained part & 0.009 & $(0.007)$ \\
\hline Unexplained part & $0.055^{* * *}$ & $(0.013)$ \\
\hline \multicolumn{3}{|c|}{ Contribution of variables to explained part } \\
\hline Age group dummies & $0.004^{* *}$ & $(0.002)$ \\
\hline East German High School & 0.001 & $(0.000)$ \\
\hline East German University & 0.000 & $(0.000)$ \\
\hline Completed apprenticeship & 0.001 & $(0.001)$ \\
\hline Foreign nationality & 0.000 & $(0.000)$ \\
\hline Parents' qualification & 0.000 & $(0.001)$ \\
\hline Master's program & $0.003^{* * *}$ & $(0.001)$ \\
\hline Study abroad experience & 0.000 & $(0.001)$ \\
\hline University of Applied Sciences & 0.000 & $(0.000)$ \\
\hline Field of study & -0.003 & $(0.004)$ \\
\hline Job type & 0.002 & $(0.003)$ \\
\hline High school GPA & 0.001 & $(0.001)$ \\
\hline Job study-related & $0.004^{* *}$ & $(0.001)$ \\
\hline Self-efficacy & -0.001 & $(0.001)$ \\
\hline Agreeableness & -0.001 & $(0.001)$ \\
\hline Conscientiousness & 0.000 & $(0.003)$ \\
\hline Openness & -0.000 & $(0.001)$ \\
\hline Neuroticism & 0.002 & $(0.004)$ \\
\hline Extraversion & $-0.003^{* *}$ & $(0.001)$ \\
\hline \multicolumn{3}{|c|}{ Contribution of variables to unexplained part } \\
\hline Age group dummies & 0.012 & $(0.018)$ \\
\hline East German High School & -0.008 & $(0.014)$ \\
\hline East German University & 0.008 & $(0.012)$ \\
\hline Completed apprenticeship & 0.008 & $(0.011)$ \\
\hline Foreign nationality & -0.013 & $(0.045)$ \\
\hline Parents' qualification & 0.008 & $(0.017)$ \\
\hline Master's program & 0.001 & $(0.007)$ \\
\hline Study abroad experience & -0.001 & $(0.008)$ \\
\hline
\end{tabular}


Table A8 continued

\begin{tabular}{lll}
\hline & Estimate & Standard error \\
\hline University of Applied Sciences & 0.001 & $(0.007)$ \\
Field of study & 0.002 & $(0.008)$ \\
Job type & $-0.081^{* *}$ & $(0.033)$ \\
High school GPA & 0.047 & $(0.035)$ \\
Job study-related & 0.000 & $(0.000)$ \\
Self-efficacy & 0.114 & $(0.089)$ \\
Agreeableness & 0.041 & $(0.044)$ \\
Conscientiousness & -0.035 & $(0.050)$ \\
Openness & 0.050 & $(0.038)$ \\
Neuroticism & $0.062^{*}$ & $(0.036)$ \\
Extraversion & -0.020 & $(0.039)$ \\
Constant & -0.140 & $(0.142)$ \\
Observations & 2780 & \\
\hline
\end{tabular}

The table shows results from a Kitagawa-Oaxaca-Blinder wage decomposition, as implemented by Jann (2008), where ability and personality measures have been added to the main specification presented in Table A7. This corresponds to the results presented in Table 3. The pooled coefficient vector is used as the reference. Heteroskedasticity-robust standard errors are reported in the second column in parentheses $*, * *, * * *$ represent statistical significance at the $10 \%-, 5 \%$ - and $1 \%$-level, respectively

Table A9 Kitagawa-Oaxaca-Blinder wage decomposition by job type

\begin{tabular}{llllll}
\hline & Stud. assist. & Jobbing & Priv. tutor. & Job req. qual. & Self-emp. \\
\hline Aggregate decomposition & & & & & \\
Mean males & $2.222^{* * *}$ & $2.174^{* * *}$ & $2.476^{* * *}$ & $2.455^{* * *}$ & $2.504^{* * *}$ \\
& $(0.005)$ & $(0.005)$ & $(0.019)$ & $(0.016)$ & $(0.025)$ \\
Mean females & $2.189^{* * *}$ & $2.098^{* * *}$ & $2.388^{* * *}$ & $2.445^{* * *}$ & $2.320^{* * *}$ \\
& $(0.004)$ & $(0.004)$ & $(0.013)$ & $(0.013)$ & $(0.022)$ \\
Difference & $0.033^{* * *}$ & $0.076^{* * *}$ & $0.088^{* * *}$ & 0.010 & $0.184^{* * *}$ \\
& $(0.006)$ & $(0.007)$ & $(0.023)$ & $(0.020)$ & $(0.033)$ \\
Explained part & $0.015^{* * *}$ & $0.027^{* * *}$ & $0.026^{* *}$ & 0.016 & 0.004 \\
& $(0.004)$ & $(0.004)$ & $(0.011)$ & $(0.010)$ & $(0.018)$ \\
Unexplained part & $0.019^{* * *}$ & $0.049^{* * *}$ & $0.062^{* * *}$ & -0.006 & $0.180^{* * *}$ \\
& $(0.006)$ & $(0.006)$ & $(0.021)$ & $(0.019)$ & $(0.035)$ \\
Contr. of variables to expl. part & & & & & \\
Survey wave fixed effects & $0.005^{* *}$ & $0.013^{* * *}$ & $0.010^{*}$ & $0.022^{* * *}$ & 0.007 \\
& $(0.002)$ & $(0.002)$ & $(0.006)$ & $(0.007)$ & $(0.006)$ \\
Age group dummies & $0.004^{* * *}$ & $0.008^{* * *}$ & $0.009^{*}$ & -0.003 & $0.014^{* *}$ \\
& $(0.001)$ & $(0.001)$ & $(0.005)$ & $(0.003)$ & $(0.006)$ \\
Socio-demographic controls & 0.000 & $0.004^{* * *}$ & 0.001 & 0.003 & -0.003 \\
& $(0.001)$ & $(0.001)$ & $(0.004)$ & $(0.004)$ & $(0.006)$ \\
\hline
\end{tabular}


Table A9 continued

\begin{tabular}{|c|c|c|c|c|c|}
\hline & Stud. assist. & Jobbing & Priv. tutor. & Job req. qual. & Self-emp. \\
\hline \multirow[t]{2}{*}{ Master's program } & $0.003^{* * *}$ & 0.000 & -0.001 & 0.005 & 0.000 \\
\hline & $(0.001)$ & $(0.000)$ & $(0.001)$ & $(0.003)$ & $(0.001)$ \\
\hline \multirow[t]{2}{*}{ Study abroad experience } & 0.000 & $-0.001^{* * *}$ & -0.000 & 0.001 & -0.007 \\
\hline & $(0.001)$ & $(0.000)$ & $(0.001)$ & $(0.002)$ & $(0.005)$ \\
\hline \multirow[t]{2}{*}{ University of Applied Sciences } & $0.001^{*}$ & -0.001 & -0.002 & -0.002 & -0.001 \\
\hline & $(0.000)$ & $(0.001)$ & $(0.001)$ & $(0.002)$ & $(0.004)$ \\
\hline \multirow[t]{2}{*}{ Field of study } & 0.001 & $0.004^{* *}$ & 0.008 & -0.009 & -0.007 \\
\hline & $(0.002)$ & $(0.002)$ & $(0.007)$ & $(0.006)$ & $(0.014)$ \\
\hline \multicolumn{6}{|l|}{ Contr. of variables to unexpl. part } \\
\hline \multirow[t]{2}{*}{ Survey wave fixed effects } & 0.003 & -0.001 & -0.000 & 0.000 & -0.007 \\
\hline & $(0.003)$ & $(0.002)$ & $(0.008)$ & $(0.010)$ & $(0.024)$ \\
\hline \multirow[t]{2}{*}{ Age group dummies } & 0.007 & -0.004 & 0.001 & $-0.151^{* * *}$ & -0.058 \\
\hline & $(0.010)$ & $(0.009)$ & $(0.053)$ & $(0.023)$ & $(0.053)$ \\
\hline \multirow[t]{2}{*}{ Socio-demographic controls } & -0.002 & 0.014 & -0.027 & 0.049 & -0.014 \\
\hline & $(0.022)$ & $(0.027)$ & $(0.076)$ & $(0.192)$ & $(0.081)$ \\
\hline \multirow[t]{2}{*}{ Master's program } & 0.005 & -0.015 & $0.070^{* *}$ & -0.010 & 0.021 \\
\hline & $(0.005)$ & $(0.010)$ & $(0.032)$ & $(0.026)$ & $(0.064)$ \\
\hline \multirow[t]{2}{*}{ Study abroad experience } & -0.001 & -0.007 & -0.006 & -0.006 & -0.005 \\
\hline & $(0.003)$ & $(0.005)$ & $(0.019)$ & $(0.021)$ & $(0.025)$ \\
\hline \multirow[t]{2}{*}{ University of Applied Sciences } & -0.001 & -0.003 & $0.046^{*}$ & 0.003 & -0.019 \\
\hline & $(0.006)$ & $(0.004)$ & $(0.026)$ & $(0.003)$ & $(0.031)$ \\
\hline \multirow[t]{2}{*}{ Field of study } & 0.001 & -0.002 & -0.027 & 0.007 & 0.014 \\
\hline & $(0.004)$ & $(0.004)$ & $(0.023)$ & $(0.009)$ & $(0.026)$ \\
\hline \multirow[t]{2}{*}{ Constant } & 0.007 & $0.067^{* *}$ & 0.007 & 0.101 & $0.247^{* *}$ \\
\hline & $(0.028)$ & $(0.032)$ & $(0.106)$ & $(0.195)$ & $(0.123)$ \\
\hline Observations & 6071 & 7966 & 1024 & 1176 & 917 \\
\hline
\end{tabular}

The table shows results from a Kitagawa-Oaxaca-Blinder wage decomposition, as implemented by Jann (2008), where the total sample is split by job type. The pooled coefficient vector is used as the reference. Heteroskedasticity-robust standard errors are reported in parentheses. "Socio-demographic controls" subsumes "East German High School," "East German University," "Completed apprenticeship," "Foreign nationality" and "Parents' qualification"

$*, * *, * * *$ represent statistical significance at the $10 \%-, 5 \%$ - and $1 \%$-level, respectively 
Table A10 Kitagawa-Oaxaca-Blinder wage decomposition including work hours and income

\begin{tabular}{|c|c|c|}
\hline & Estimate & Standard error \\
\hline \multicolumn{3}{|l|}{ Aggregate decomposition } \\
\hline Mean males & $2.220^{* * *}$ & $(0.005)$ \\
\hline Mean females & $2.155^{* * *}$ & $(0.003)$ \\
\hline Difference & $0.065^{* * *}$ & $(0.006)$ \\
\hline Explained part & $0.025^{* * *}$ & $(0.003)$ \\
\hline Unexplained part & $0.040^{* * *}$ & $(0.005)$ \\
\hline \multicolumn{3}{|c|}{ Contribution of variables to explained part } \\
\hline Survey wave fixed effects & $0.006^{* * *}$ & $(0.001)$ \\
\hline Age group dummies & $0.008^{* * *}$ & $(0.001)$ \\
\hline East German High School & $0.001^{* * *}$ & $(0.001)$ \\
\hline East German University & 0.000 & $(0.000)$ \\
\hline Completed apprenticeship & -0.000 & $(0.000)$ \\
\hline Foreign nationality & -0.000 & $(0.000)$ \\
\hline Parents' qualification & 0.000 & $(0.000)$ \\
\hline Master's program & $0.001^{* * *}$ & $(0.000)$ \\
\hline Study abroad experience & $-0.001^{* * *}$ & $(0.000)$ \\
\hline University of Applied Sciences & -0.000 & $(0.000)$ \\
\hline Field of study & $0.003^{*}$ & $(0.002)$ \\
\hline Job type & $0.008^{* * *}$ & $(0.002)$ \\
\hline Log work hours per week & $-0.001^{* * *}$ & $(0.000)$ \\
\hline Log income excluding work income & 0.000 & $(0.000)$ \\
\hline \multicolumn{3}{|c|}{ Contribution of variables to unexplained part } \\
\hline Survey wave fixed effects & -0.000 & $(0.001)$ \\
\hline Age group dummies & -0.011 & $(0.009)$ \\
\hline East German High School & 0.007 & $(0.006)$ \\
\hline East German University & $-0.010^{*}$ & $(0.006)$ \\
\hline Completed apprenticeship & -0.004 & $(0.005)$ \\
\hline Foreign nationality & 0.018 & $(0.019)$ \\
\hline Parents' qualification & -0.005 & $(0.009)$ \\
\hline Master's program & 0.004 & $(0.007)$ \\
\hline Study abroad experience & -0.004 & $(0.004)$ \\
\hline University of Applied Sciences & 0.005 & $(0.004)$ \\
\hline Field of study & 0.003 & $(0.003)$ \\
\hline Job type & -0.004 & $(0.007)$ \\
\hline Log work hours per week & -0.003 & $(0.022)$ \\
\hline
\end{tabular}


Table A10 continued

\begin{tabular}{lll}
\hline & Estimate & Standard error \\
\hline Log income excluding work income & 0.080 & $(0.057)$ \\
Constant & -0.034 & $(0.070)$ \\
Observations & 12,835 & \\
\hline
\end{tabular}

The table shows results from a Kitagawa-Oaxaca-Blinder wage decomposition, as implemented by Jann (2008), where logarithmized work hours per week and logarithmized income excluding work income have been added to the main specification presented in Table A7. The pooled coefficient vector is used as the reference. Heteroskedasticity-robust standard errors are reported in the second column in parentheses $*, * *, * * *$ represent statistical significance at the $10 \%-, 5 \%$ - and $1 \%$-level, respectively

Table A11 Wage regression with Heckman (1979) correction for selection bias

\begin{tabular}{|c|c|c|c|}
\hline & (1) & (2) & (3) \\
\hline \multicolumn{4}{|l|}{ Log hourly wage } \\
\hline Female & $\begin{array}{l}-0.042^{* * *} \\
(0.005)\end{array}$ & $\begin{array}{l}-0.039^{* * *} \\
(0.005)\end{array}$ & $\begin{array}{l}-0.040^{* * *} \\
(0.005)\end{array}$ \\
\hline \multicolumn{4}{|l|}{ Job type } \\
\hline Jobbing & $\begin{array}{l}-0.047^{* * *} \\
(0.004)\end{array}$ & $\begin{array}{l}-0.046^{* * *} \\
(0.004)\end{array}$ & $\begin{array}{l}-0.046^{* * *} \\
(0.004)\end{array}$ \\
\hline Private tutoring & $\begin{array}{l}0.238^{* * *} \\
(0.011)\end{array}$ & $\begin{array}{l}0.240^{* * *} \\
(0.011)\end{array}$ & $\begin{array}{l}0.240^{* * *} \\
(0.011)\end{array}$ \\
\hline Job requiring qualification & $\begin{array}{l}0.238^{* * *} \\
(0.011)\end{array}$ & $\begin{array}{l}0.235^{* * *} \\
(0.012)\end{array}$ & $\begin{array}{l}0.234^{* * *} \\
(0.012)\end{array}$ \\
\hline Self-employed work & $\begin{array}{l}0.294 * * * \\
(0.017)\end{array}$ & $\begin{array}{l}0.285^{* * *} \\
(0.017)\end{array}$ & $\begin{array}{l}0.285^{* * *} \\
(0.017)\end{array}$ \\
\hline Other & $\begin{array}{l}0.102^{* * *} \\
(0.012)\end{array}$ & $\begin{array}{l}0.097^{* * *} \\
(0.012)\end{array}$ & $\begin{array}{l}0.096^{* * *} \\
(0.012)\end{array}$ \\
\hline Survey wave fixed effects & Yes & Yes & Yes \\
\hline Age group dummies & Yes & Yes & Yes \\
\hline Further demographic controls & Yes & Yes & Yes \\
\hline Field of study & No & Yes & No \\
\hline Other study characteristics & Yes & Yes & Yes \\
\hline \multicolumn{4}{|l|}{ Selection into working } \\
\hline Female & $\begin{array}{l}0.105^{* * *} \\
(0.014)\end{array}$ & $\begin{array}{l}0.095^{* * *} \\
(0.014)\end{array}$ & $\begin{array}{l}0.095^{* * *} \\
(0.014)\end{array}$ \\
\hline \multicolumn{4}{|l|}{ Field of Study } \\
\hline Social sciences, law & $\begin{array}{l}-0.108^{* * *} \\
(0.018)\end{array}$ & $\begin{array}{l}-0.082^{* * *} \\
(0.019)\end{array}$ & $\begin{array}{l}0.468^{* *} \\
(0.227)\end{array}$ \\
\hline
\end{tabular}


Table A11 continued

\begin{tabular}{llll}
\hline & $(1)$ & $(2)$ & $(3)$ \\
\hline Natur. scienc., engineer. & $-0.246^{* * *}$ & $-0.246^{* * *}$ & -0.200 \\
& $(0.018)$ & $(0.019)$ & $(0.215)$ \\
Human and Vet. Medicine & $-0.392^{* * *}$ & $-0.350^{* * *}$ & $-1.371^{* * *}$ \\
& $(0.023)$ & $(0.024)$ & $(0.283)$ \\
Log income excl. work income & & $-0.404^{* * *}$ & $-0.397^{* * *}$ \\
& & $(0.014)$ & $(0.027)$ \\
Interactions of study fields with non-work income & & & \\
Social sciences, law $\times$ non-work income & & & $-0.087^{* *}$ \\
& & & $(0.036)$ \\
Natur. scienc., engineer. $\times$ non-work income & & & -0.007 \\
& & & $(0.034)$ \\
Human and Vet. Medicine $\times$ non-work income & & & $0.161^{* * *}$ \\
Survey wave fixed effects & & Yes & $(0.045)$ \\
Age group dummies & Yes & Yes & Yes \\
Further demographic controls & Yes & Yes & Yes \\
Other study characteristics & Yes & Yes & Yes \\
Selected observations & Yes & 18,157 & 18,157 \\
Non-selected observations & 19,024 & 19,787 & 19,787 \\
$\rho$ & 20,217 & 0.010 & -0.001 \\
Wald $\chi^{2}$ & -0.024 & 0.048 & 0.001 \\
Wald $p$ value & 0.292 & 0.827 & 0.979 \\
The & 0.589 & & \\
\hline
\end{tabular}

The table shows results from linear regressions of wages on the full set of covariates used in Table 2, column (5) (except field of study in columns (1) and (3)), but using the Heckman (1979) procedure to correct for bias arising from selection into work. The three columns present estimates from three models which differ in their specification of the selection equation as seen. The variables indicated by "Yes" are included in both the selection and the outcome equation. $\rho$ is the estimated correlation of the error terms of the two equations, and the $\chi^{2}$ statistic and $p$ value refer to a Wald test of independent equations. For categorical variables, the base categories (omitted in the table) are "Humanities" for Field of Study and "Student/research assistant" for Job type. Heteroskedasticity-robust standard errors are reported in parentheses $*, * *, * * *$ represent statistical significance at the $10 \%-, 5 \%$ - and $1 \%$-level, respectively 


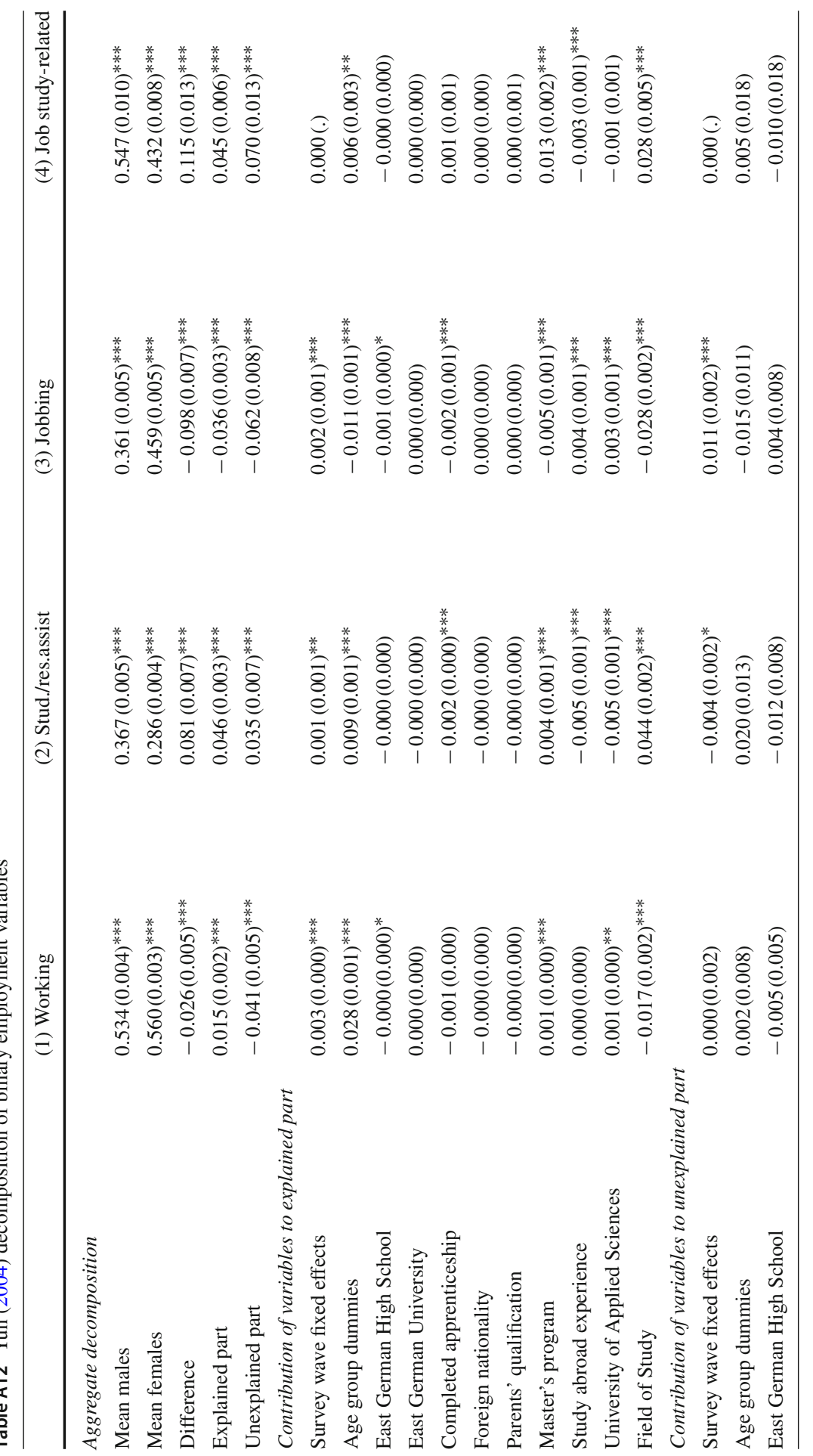




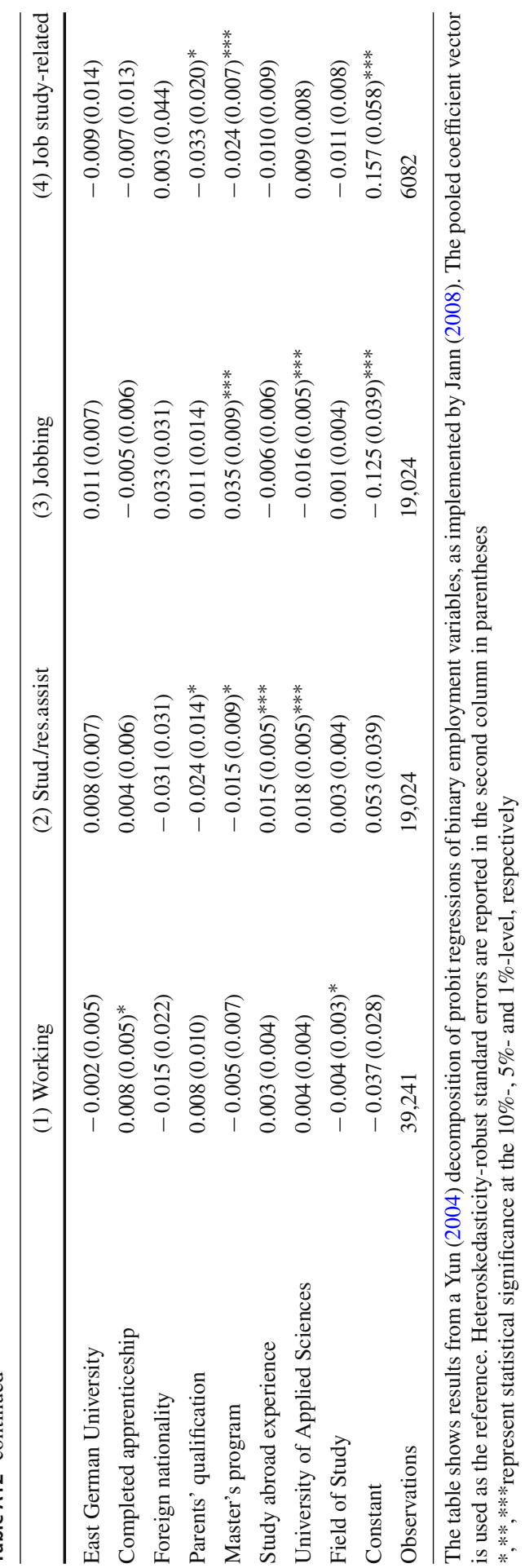


Table A13 Wage regression without type of university

\begin{tabular}{|c|c|c|c|c|}
\hline & \multicolumn{2}{|c|}{ Without type of university } & \multicolumn{2}{|c|}{ Original specification } \\
\hline & (1) & (2) & (3) & (4) \\
\hline Female & $\begin{array}{l}-0.049^{* * *} \\
(0.005)\end{array}$ & $\begin{array}{l}-0.041^{* * *} \\
(0.005)\end{array}$ & $\begin{array}{l}-0.049^{* * *} \\
(0.005)\end{array}$ & $\begin{array}{l}-0.041^{* * *} \\
(0.005)\end{array}$ \\
\hline East German High School & $\begin{array}{l}-0.077^{* * *} \\
(0.009)\end{array}$ & $\begin{array}{l}-0.068^{* * *} \\
(0.008)\end{array}$ & $\begin{array}{l}-0.077^{* * *} \\
(0.009)\end{array}$ & $\begin{array}{l}-0.068^{* * *} \\
(0.008)\end{array}$ \\
\hline East German University & $\begin{array}{l}-0.061^{* * *} \\
(0.009)\end{array}$ & $\begin{array}{l}-0.062^{* * *} \\
(0.008)\end{array}$ & $\begin{array}{l}-0.061^{* * *} \\
(0.009)\end{array}$ & $\begin{array}{l}-0.062^{* * *} \\
(0.008)\end{array}$ \\
\hline Completed apprenticeship & $\begin{array}{l}0.033^{* * *} \\
(0.007)\end{array}$ & $\begin{array}{l}-0.004 \\
(0.007)\end{array}$ & $\begin{array}{l}0.035^{* * *} \\
(0.007)\end{array}$ & $\begin{array}{l}-0.002 \\
(0.007)\end{array}$ \\
\hline Foreign nationality & $\begin{array}{l}-0.029 \\
(0.019)\end{array}$ & $\begin{array}{l}-0.029 \\
(0.018)\end{array}$ & $\begin{array}{l}-0.029 \\
(0.019)\end{array}$ & $\begin{array}{l}-0.029 \\
(0.018)\end{array}$ \\
\hline \multicolumn{5}{|l|}{ Parents' qualification } \\
\hline Apprent./skilled worker & $\begin{array}{l}0.044^{* * *} \\
(0.015)\end{array}$ & $\begin{array}{l}0.037^{* *} \\
(0.015)\end{array}$ & $\begin{array}{l}0.044^{* * *} \\
(0.015)\end{array}$ & $\begin{array}{l}0.037^{* *} \\
(0.015)\end{array}$ \\
\hline Master craft./tech. school & $\begin{array}{l}0.055^{* * *} \\
(0.016)\end{array}$ & $\begin{array}{l}0.044^{* * *} \\
(0.015)\end{array}$ & $\begin{array}{l}0.055^{* * *} \\
(0.016)\end{array}$ & $\begin{array}{l}0.044^{* * *} \\
(0.015)\end{array}$ \\
\hline Academic degree & $\begin{array}{l}0.071^{* * *} \\
(0.015)\end{array}$ & $\begin{array}{l}0.055^{* * *} \\
(0.014)\end{array}$ & $\begin{array}{l}0.071^{* * *} \\
(0.015)\end{array}$ & $\begin{array}{l}0.055^{* * *} \\
(0.014)\end{array}$ \\
\hline Master's program & $\begin{array}{l}0.046^{* * *} \\
(0.007)\end{array}$ & $\begin{array}{l}0.037^{* * *} \\
(0.007)\end{array}$ & $\begin{array}{l}0.045^{* * *} \\
(0.007)\end{array}$ & $\begin{array}{l}0.036^{* * *} \\
(0.007)\end{array}$ \\
\hline Study abroad experience & $\begin{array}{l}0.015^{* * *} \\
(0.006)\end{array}$ & $\begin{array}{l}0.017^{* * *} \\
(0.005)\end{array}$ & $\begin{array}{l}0.015^{* * *} \\
(0.006)\end{array}$ & $\begin{array}{l}0.017^{* * *} \\
(0.005)\end{array}$ \\
\hline \multicolumn{5}{|l|}{ Field of Study } \\
\hline Social sciences, law & $\begin{array}{l}-0.018^{* * *} \\
(0.006)\end{array}$ & $\begin{array}{l}-0.004 \\
(0.006)\end{array}$ & $\begin{array}{l}-0.016^{* *} \\
(0.006)\end{array}$ & $\begin{array}{l}-0.002 \\
(0.006)\end{array}$ \\
\hline Natur. scienc., engineer. & $\begin{array}{l}-0.011^{*} \\
(0.007)\end{array}$ & $\begin{array}{l}-0.002 \\
(0.006)\end{array}$ & $\begin{array}{l}-0.010 \\
(0.007)\end{array}$ & $\begin{array}{l}-0.001 \\
(0.006)\end{array}$ \\
\hline Human and Vet. Medicine & $\begin{array}{l}-0.006 \\
(0.008)\end{array}$ & $\begin{array}{l}-0.006 \\
(0.008)\end{array}$ & $\begin{array}{l}-0.005 \\
(0.008)\end{array}$ & $\begin{array}{l}-0.006 \\
(0.008)\end{array}$ \\
\hline \multicolumn{5}{|l|}{ Job type } \\
\hline Jobbing & & $\begin{array}{l}-0.047^{* * *} \\
(0.004)\end{array}$ & & $\begin{array}{l}-0.046^{* * *} \\
(0.004)\end{array}$ \\
\hline Private tutoring & & $\begin{array}{l}0.237^{* * *} \\
(0.011)\end{array}$ & & $\begin{array}{l}0.237^{* * *} \\
(0.011)\end{array}$ \\
\hline
\end{tabular}


Table A13 continued

\begin{tabular}{|c|c|c|c|c|}
\hline & \multicolumn{2}{|c|}{ Without type of university } & \multicolumn{2}{|c|}{ Original specification } \\
\hline & (1) & (2) & (3) & (4) \\
\hline \multirow[t]{2}{*}{ Job requiring qualification } & & $0.238^{* * *}$ & & $0.238^{* * *}$ \\
\hline & & $(0.011)$ & & $(0.011)$ \\
\hline \multirow[t]{2}{*}{ Self-employed work } & & $0.294^{* * *}$ & & $0.294^{* * *}$ \\
\hline & & $(0.017)$ & & $(0.017)$ \\
\hline \multirow[t]{2}{*}{ Other } & & $0.101^{* * *}$ & & $0.102^{* * *}$ \\
\hline & & $(0.012)$ & & $(0.012)$ \\
\hline \multirow[t]{2}{*}{ Uni. of Applied Sciences } & & & -0.008 & -0.006 \\
\hline & & & $(0.006)$ & $(0.006)$ \\
\hline Survey wave fixed effects & Yes & Yes & Yes & Yes \\
\hline Age group dummies & Yes & Yes & Yes & Yes \\
\hline Mean dep. var. & 2.213 & 2.213 & 2.213 & 2.213 \\
\hline R-squared & 0.128 & 0.227 & 0.128 & 0.227 \\
\hline Observations & 19,024 & 19,024 & 19,024 & 19,024 \\
\hline
\end{tabular}

Columns (1) and (2) of this table show results of wage regressions identical to those in columns (4) and (5) of Table 2, the only difference being that the type of university is not included in the covariates. Columns (3) and (4) reproduce columns (4) and (5) from Table 2 for comparison. For categorical variables, the base categories (omitted in the table) are "No qualification" for Parents' qualification, "Humanities" for Field of Study and "Student/research assistant" for Job type. Heteroskedasticity-robust standard errors are reported in parentheses $*, * *, * * *$ represent statistical significance at the $10 \%-, 5 \%-$ and $1 \%$-level, respectively 


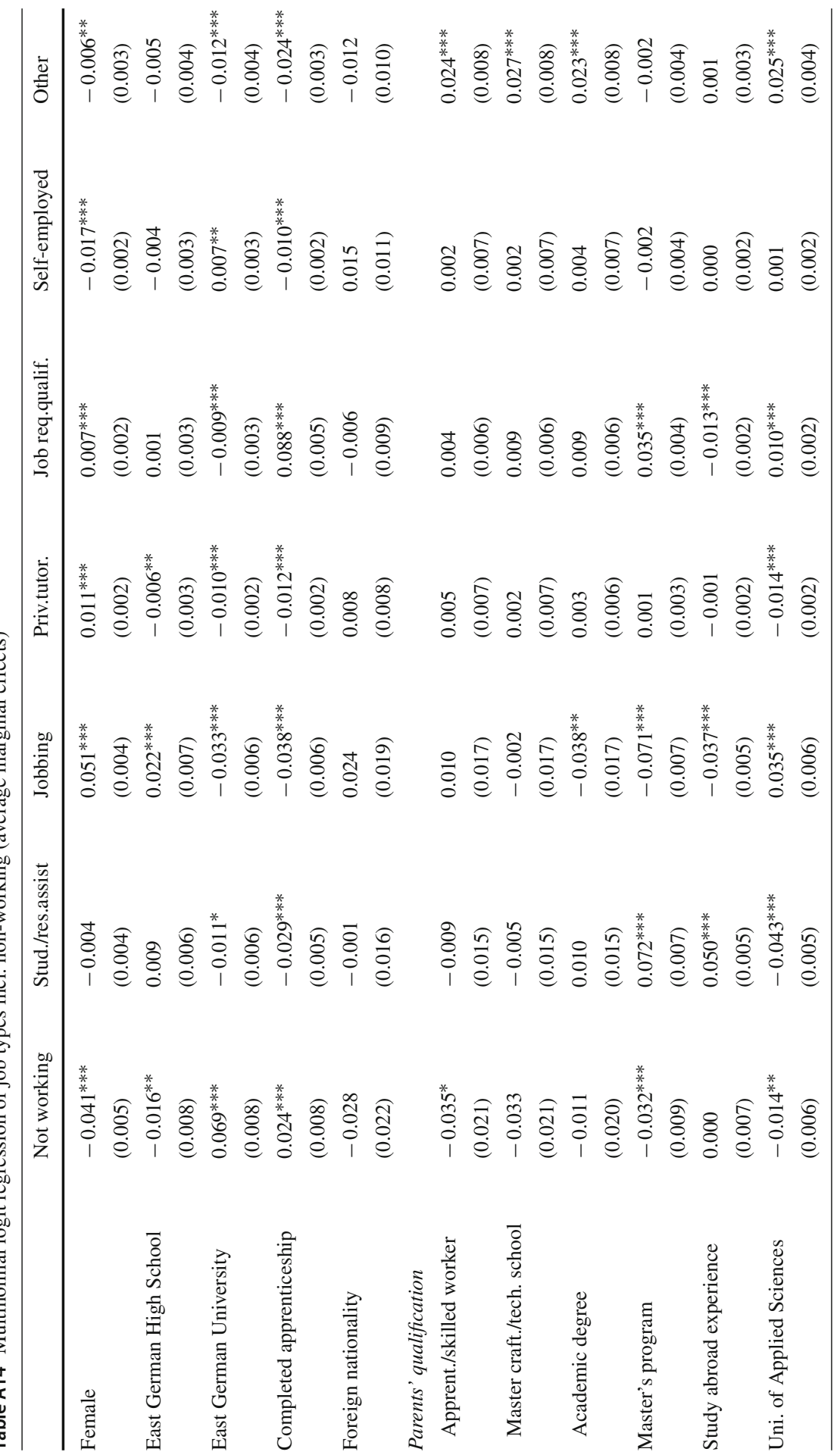




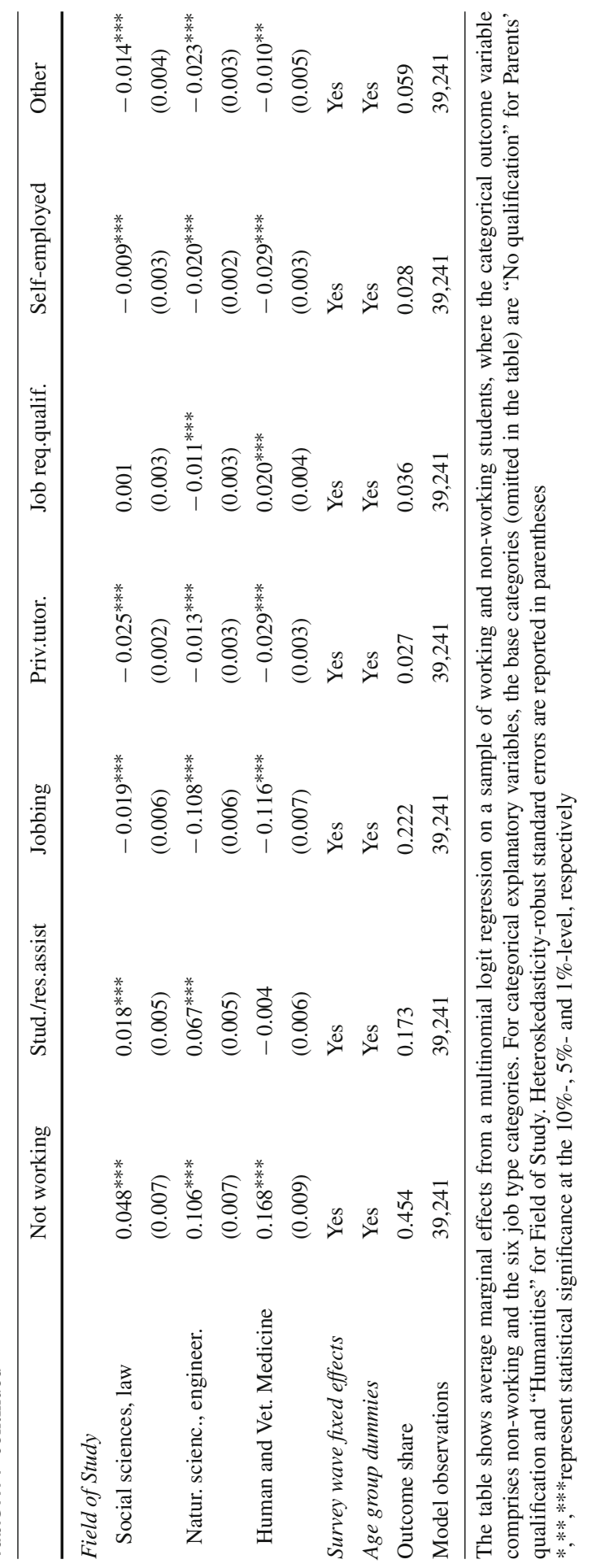




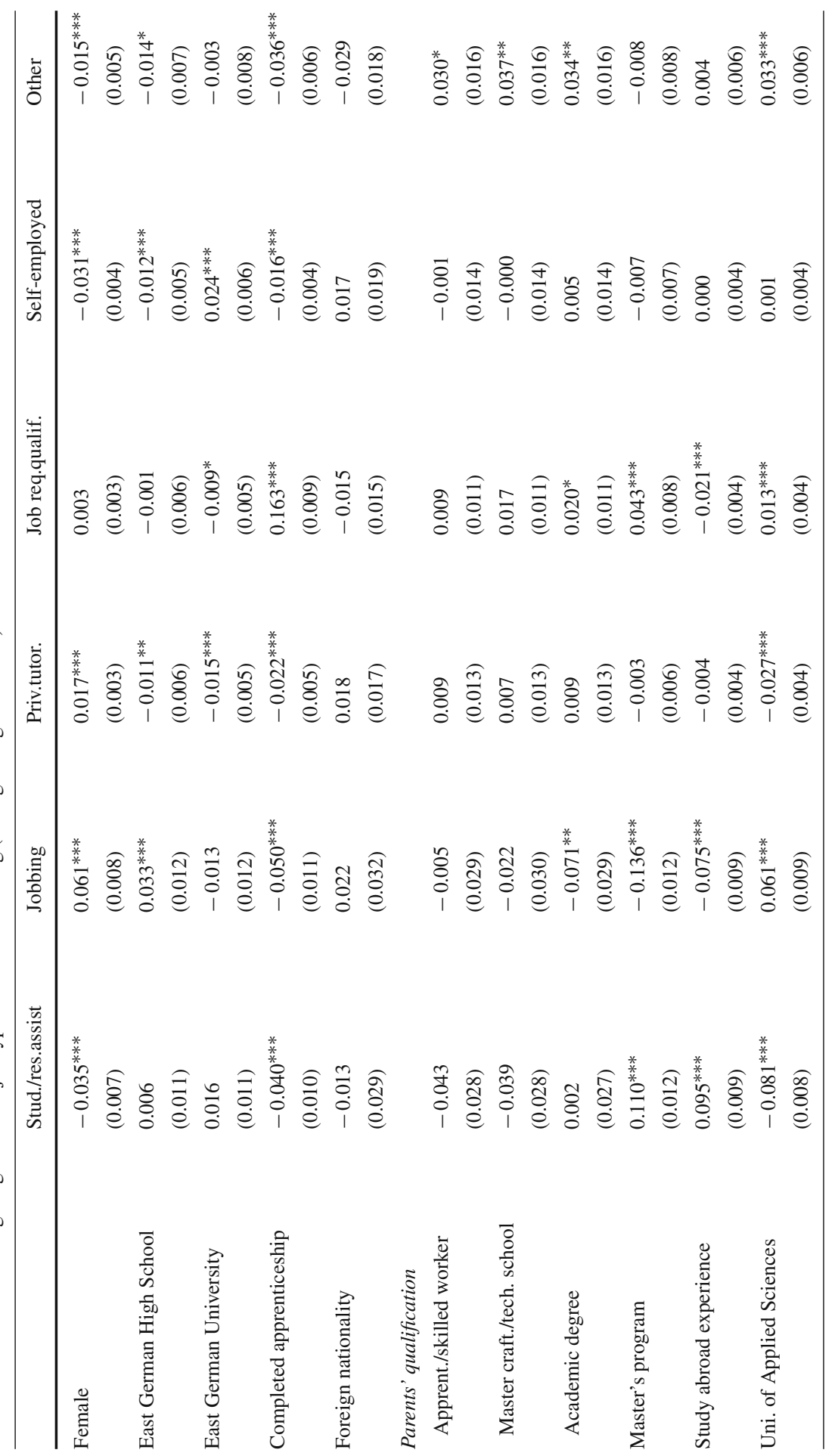




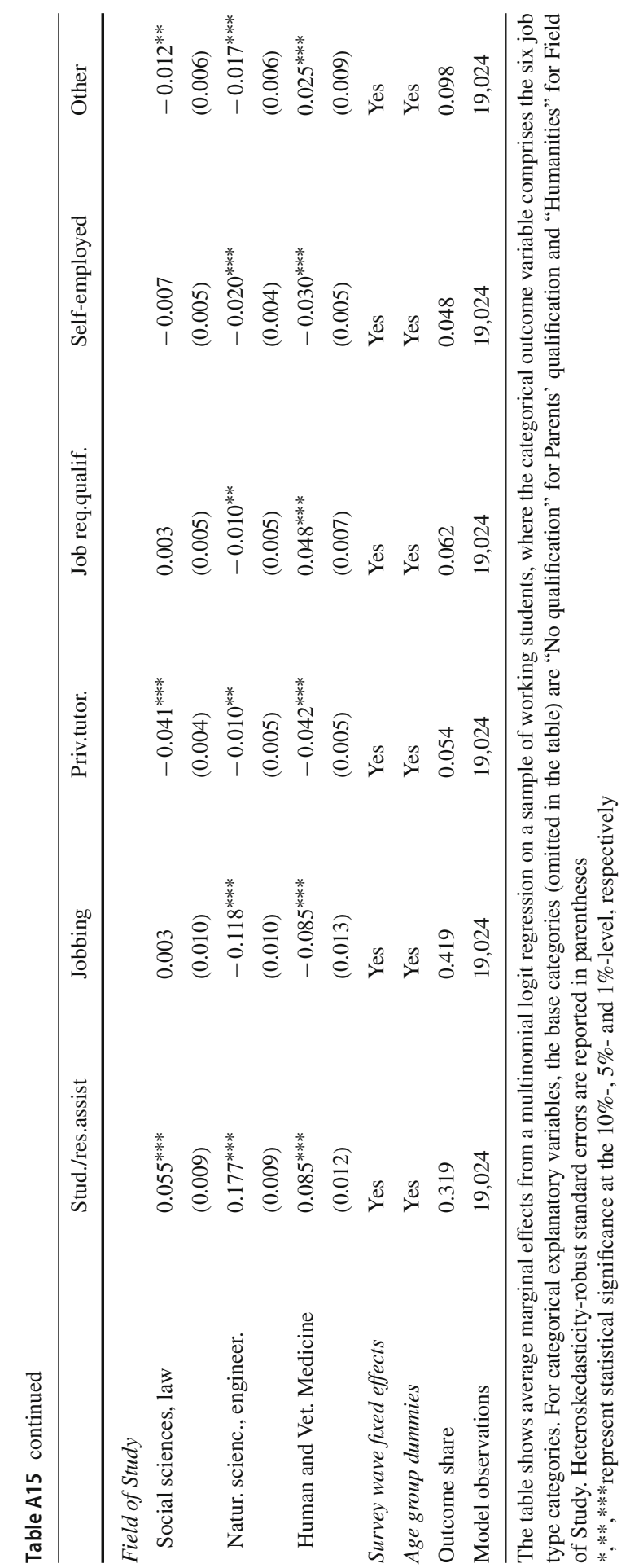




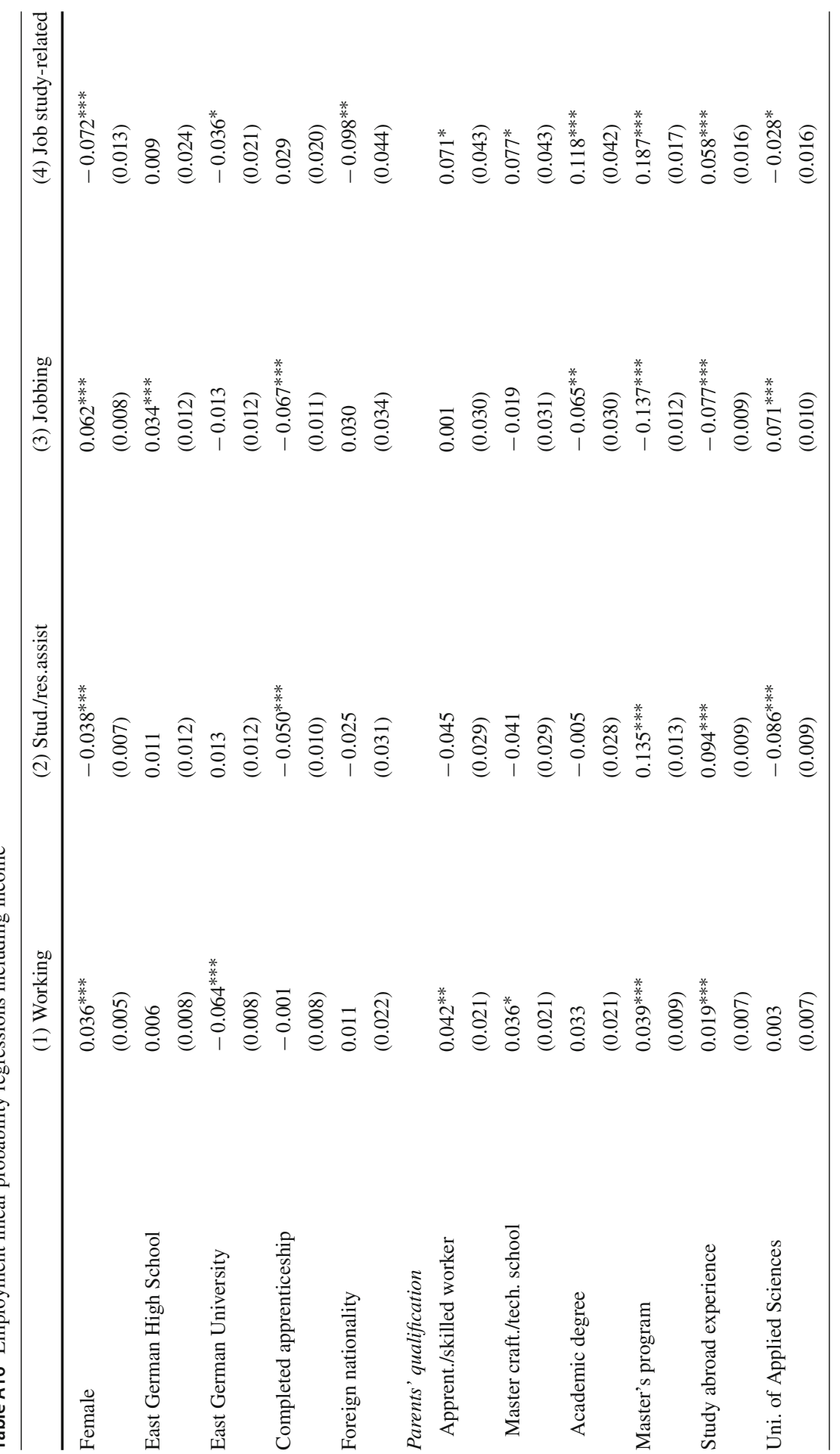




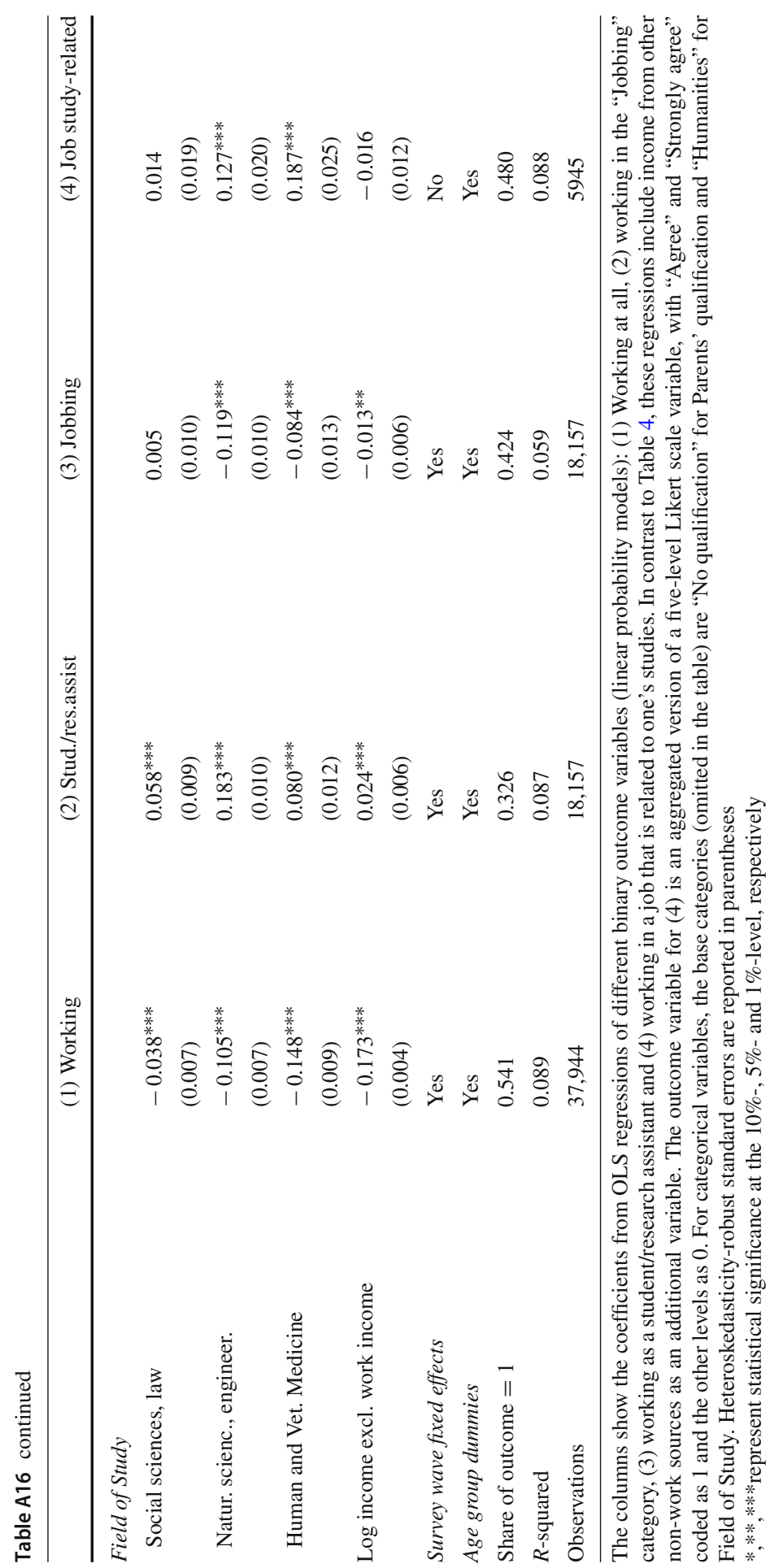




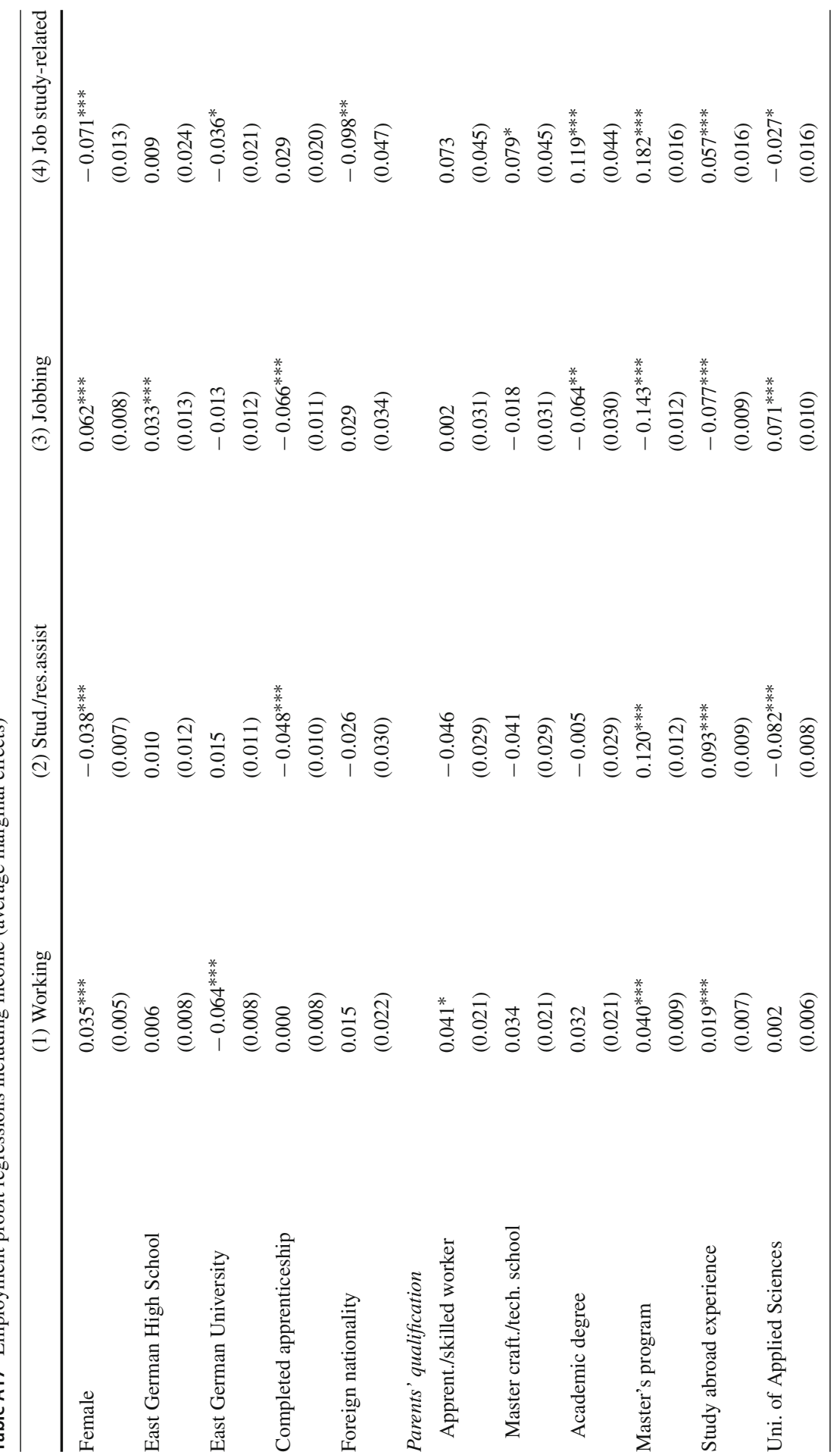




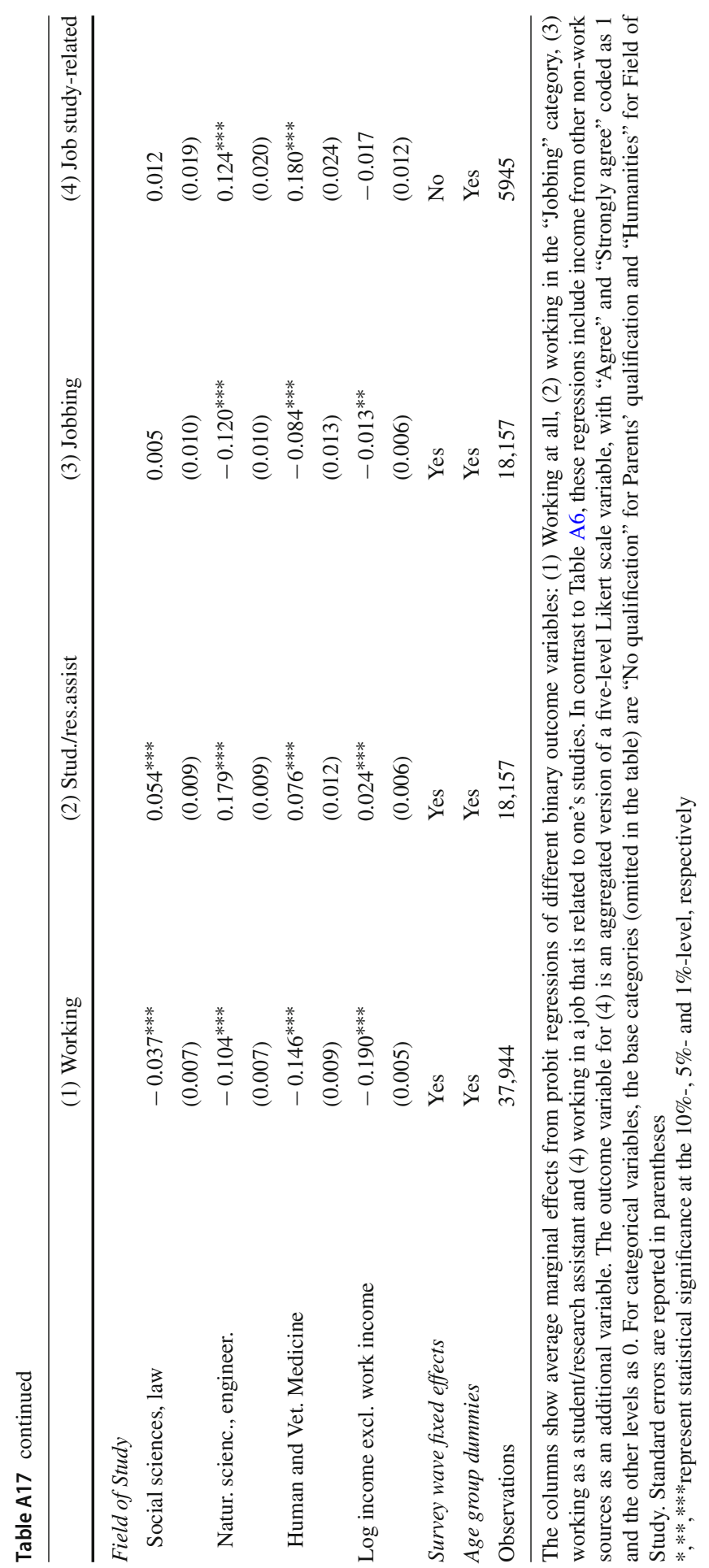




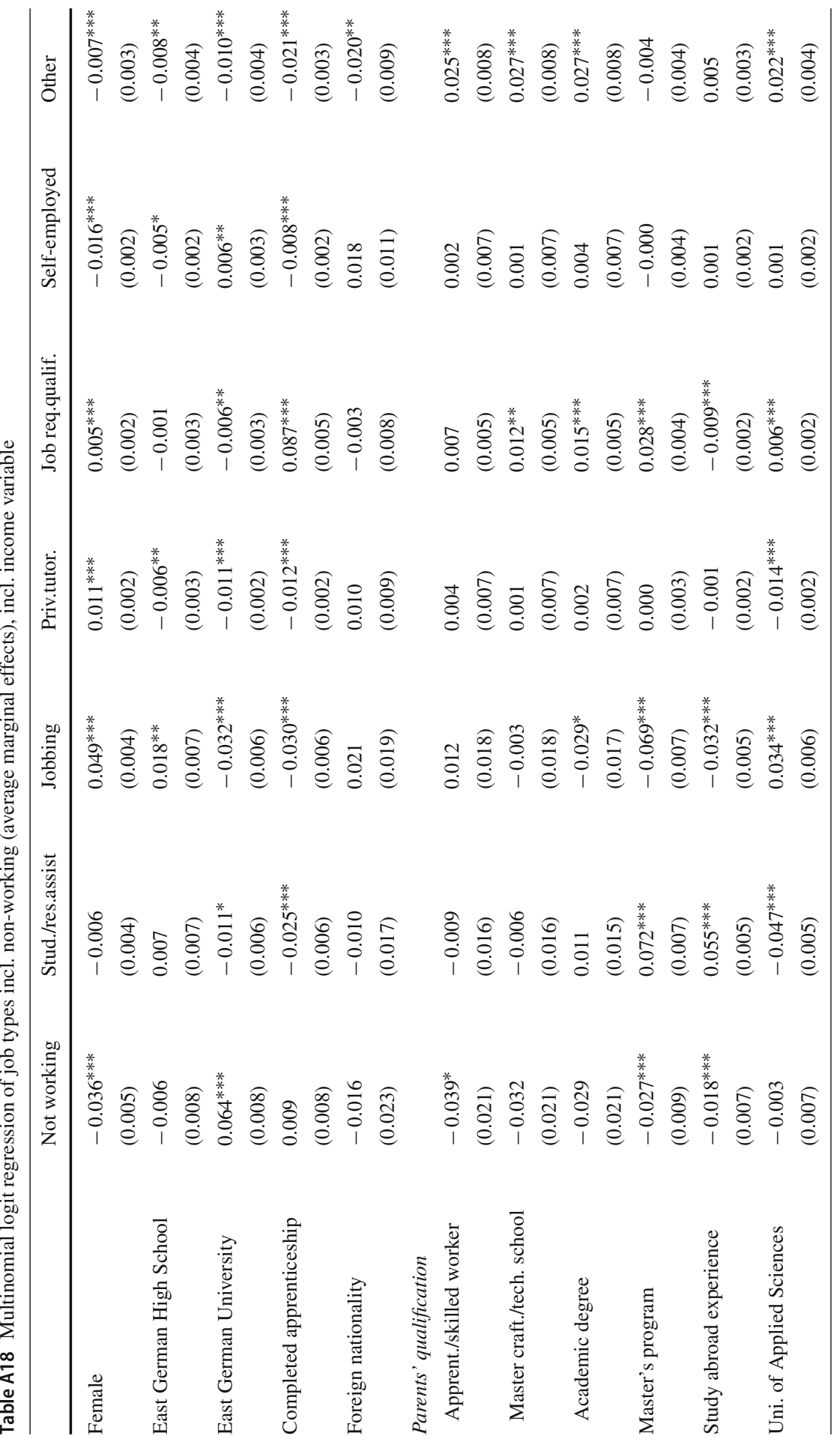




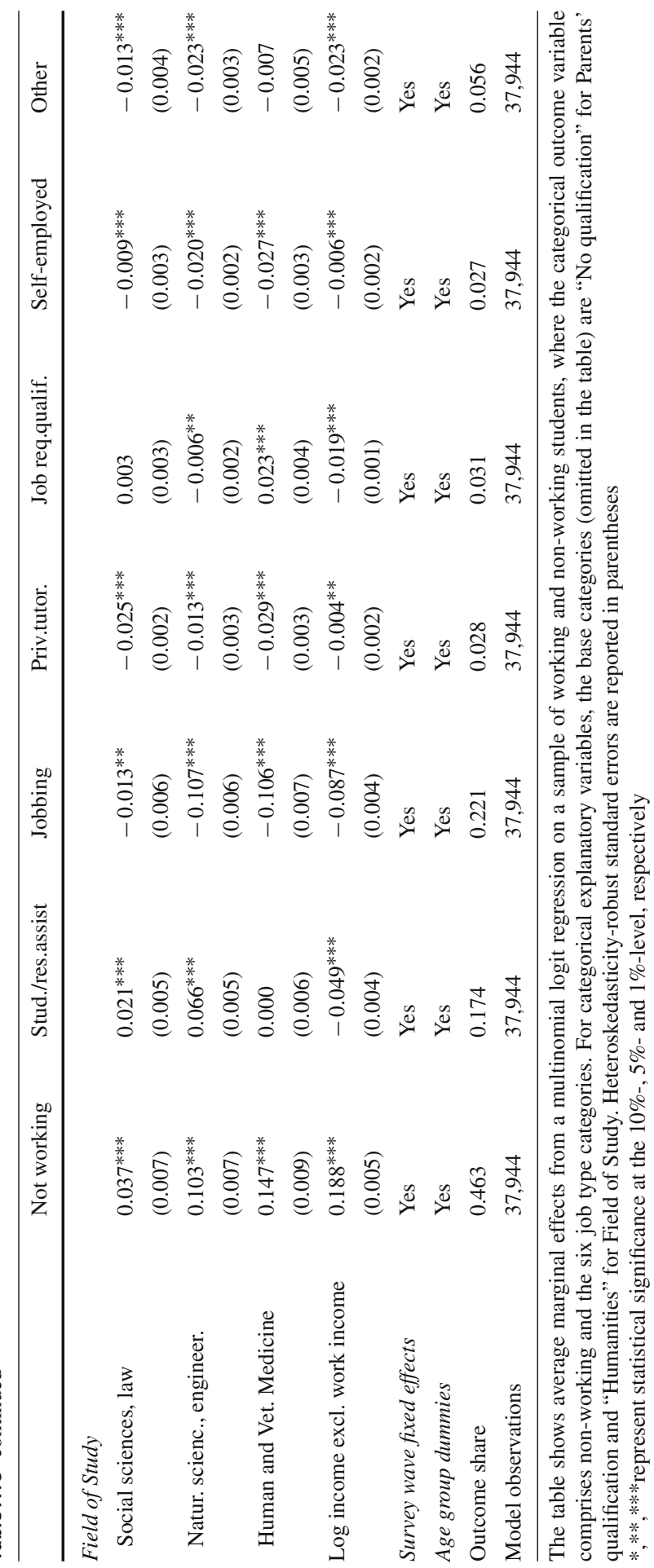




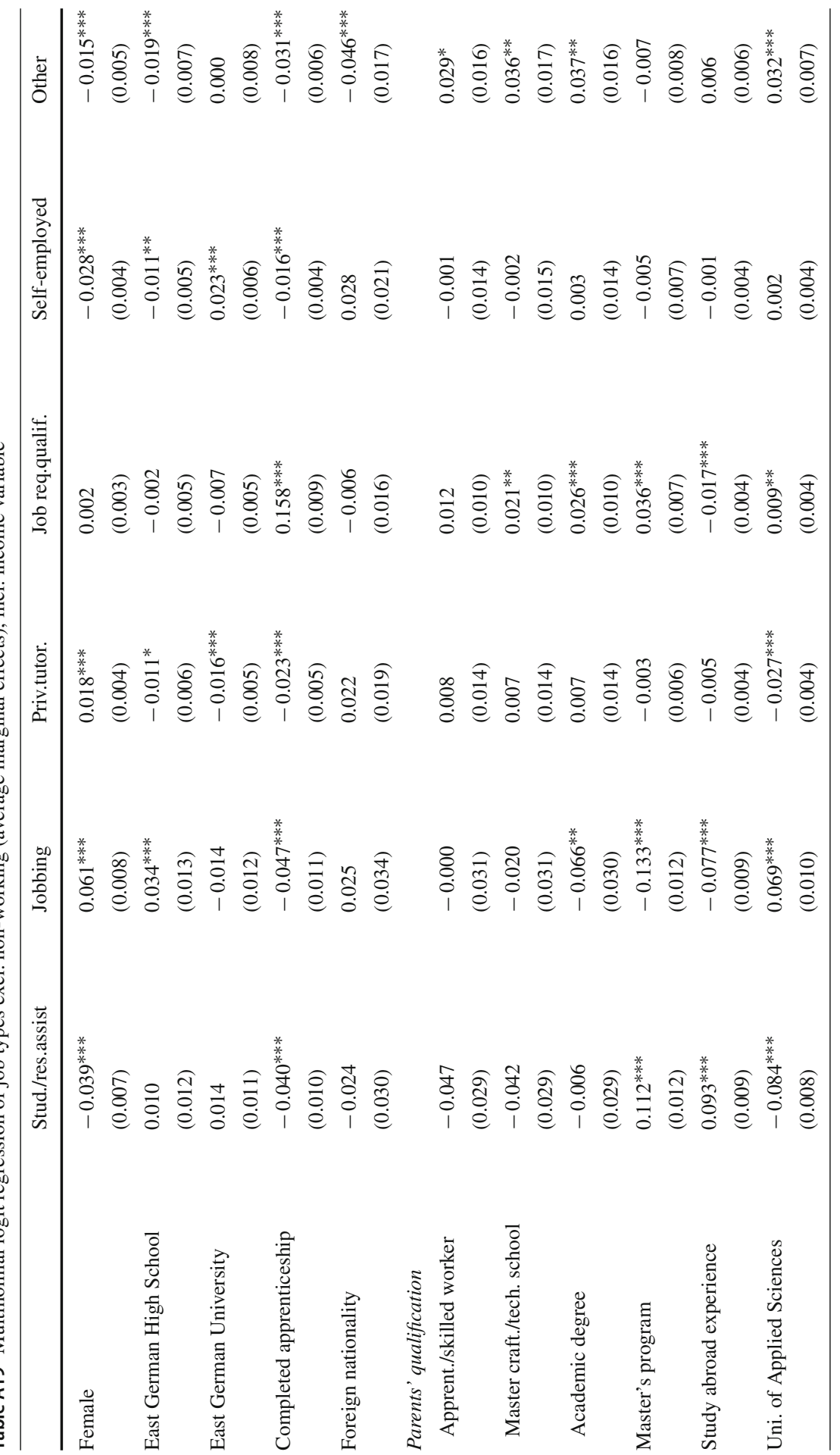




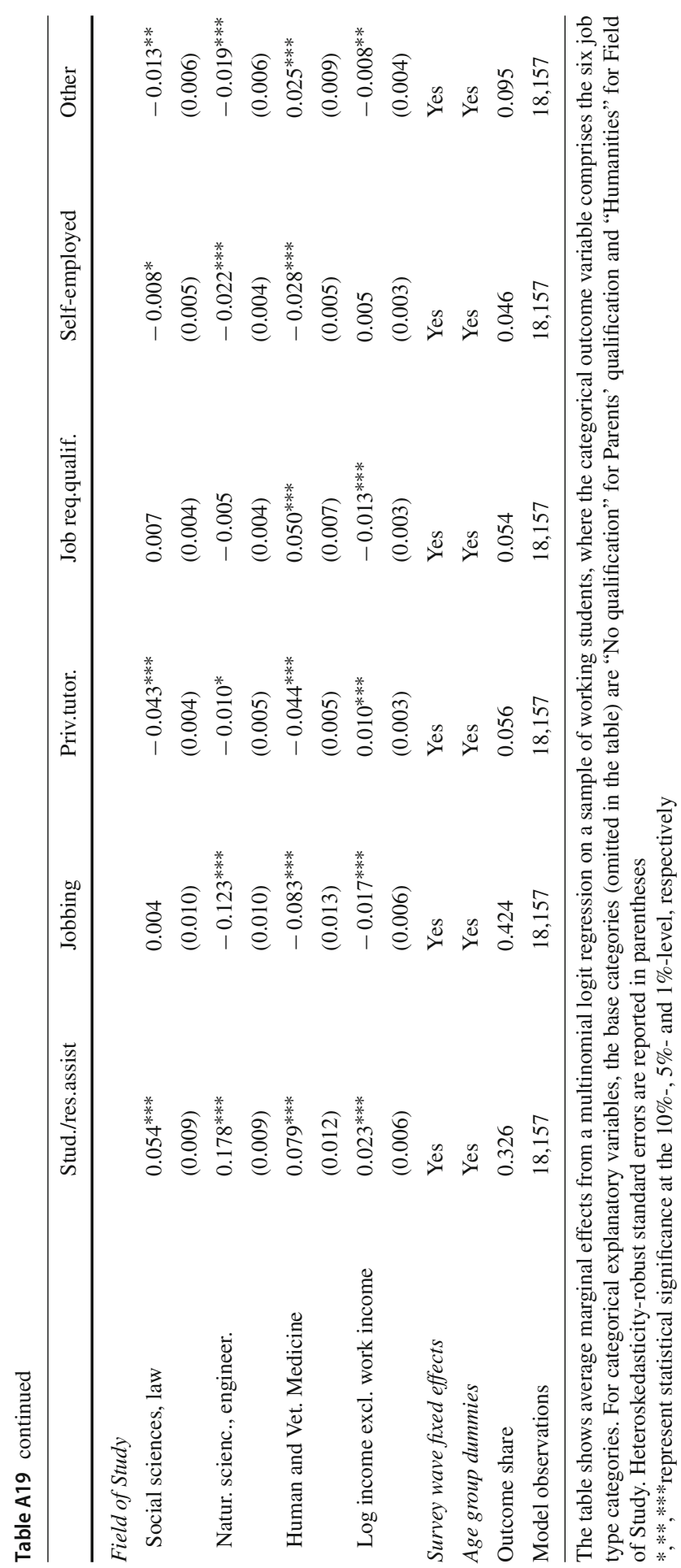




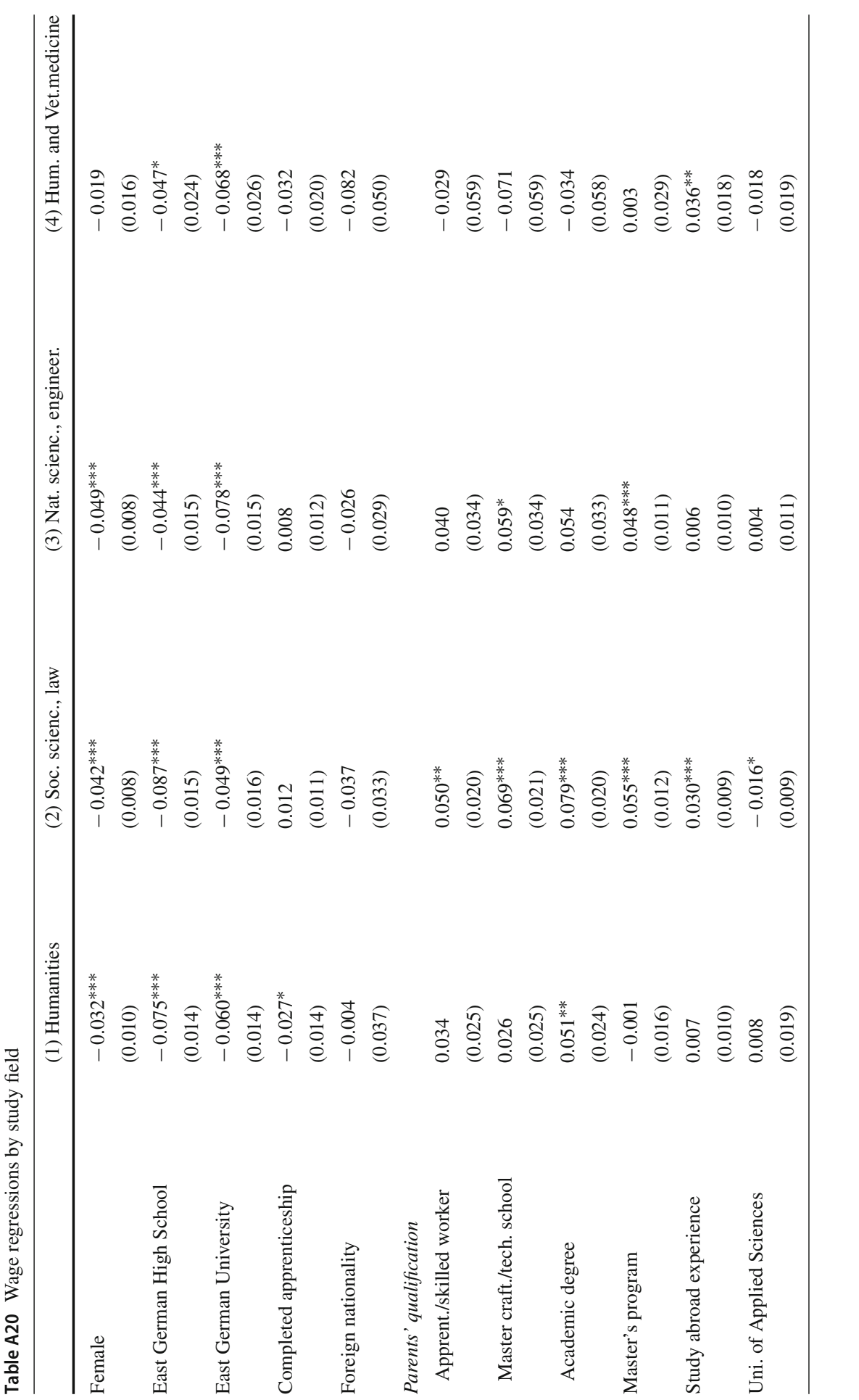




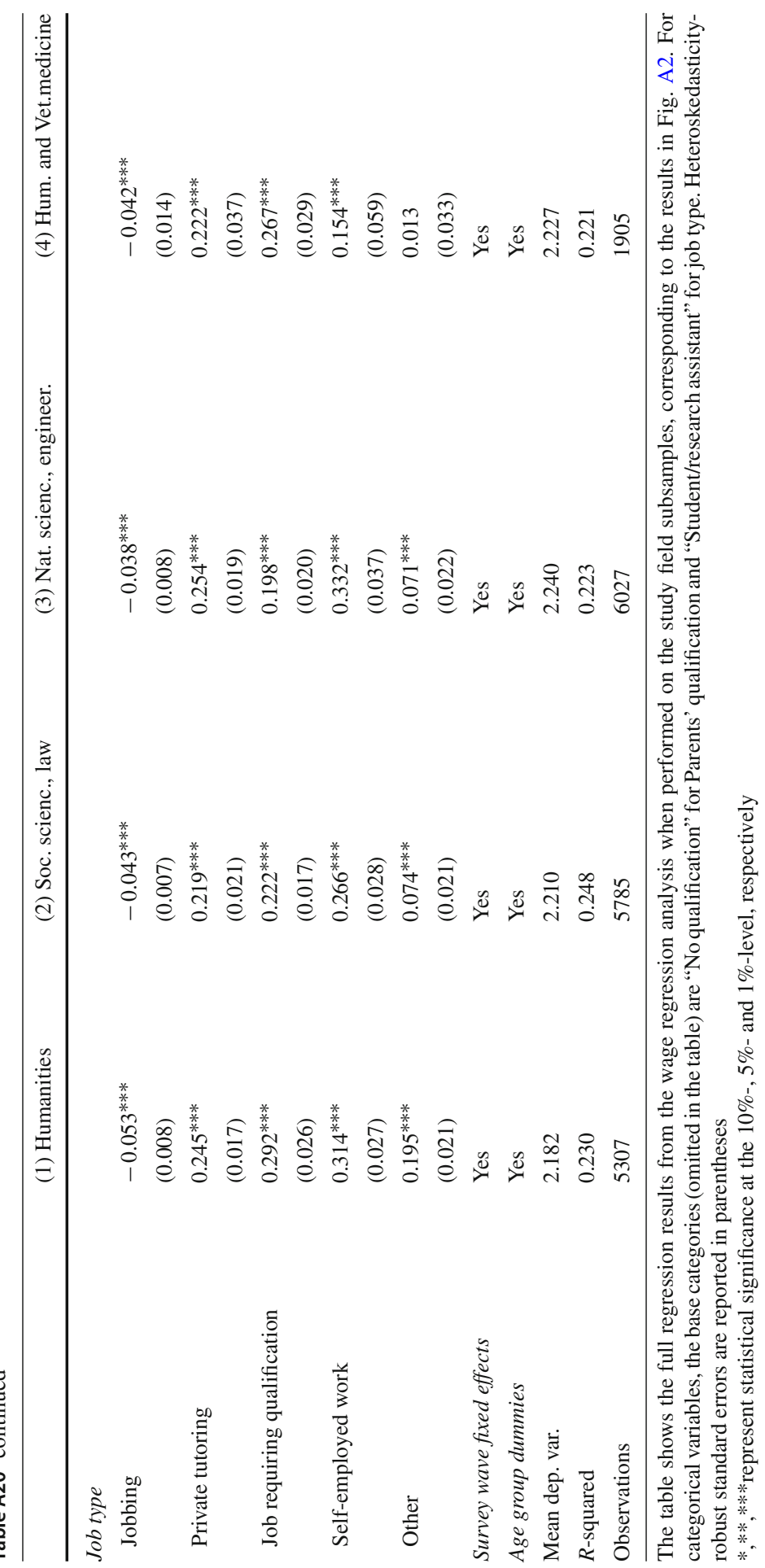




\section{References}

Albrecht J, Bronson MA, Thoursie PS, Vroman S (2018) The career dynamics of high-skilled women and men: evidence from Sweden. Eur Econ Rev 105:83-102

Altonji JG, Arcidiacono P, Maurel A (2016) The analysis of field choice in college and graduate school. In: Hanushek EA, Machin S, Woessmann L (eds) Handbook of the economics of education. Handbooks in economics, vol 5. North Holland, Amsterdam, pp 305-396

Auspurg K, Hinz T, Sauer C (2017) Why should women get less? Evidence on the gender pay gap from multifactorial survey experiments. Am Sociol Rev 82(1):179-210

Autorengruppe Bildungsberichterstattung (2020) Bildung in Deutschland 2020: Ein indikatorengestützter Bericht mit einer Analyse zu Bildung in einer digitalisierten Welt, 1st edn. wbv Media, Bielefeld

Beierlein C, Kemper C, Kovaleva A, Rammstedt B (2013) Short scale for measuring general self-efficacy beliefs (ASKU). Methoden Daten Analysen 7:251-278

Bertrand M (2011) New perspectives on gender. In: Ashenfelter O, Card DE (eds) Handbook of labor economics, handbooks in economics, vol 4. Elsevier, Amsterdam, pp 1543-1590

Blau FD, Kahn LM (2017) The gender wage gap: extent, trends, and explanations. J Econ Lit 55(3):789-865

Briel S, Osikominu A, Pfeifer G, Reutter M, Satlukal S (2021) Gender differences in wage expectations: the role of biased beliefs. Empir Econ

Bütikofer A, Jensen S, Salvanes KG (2018) The role of parenthood on the gender gap among top earners. Eur Econ Rev 109(C):103-123

Buckles K (2019) Fixing the leaky pipeline: strategies for making economics work for women at every stage. J Econ Perspect 33(1):43-60

Carrell SE, Page ME, West JE (2010) Sex and science: how professor gender perpetuates the gender gap. Q J Econ 125(3):1101-1144

Destatis (2019) Verdienstunterschied zwischen Frauen und Männern 2018 unverändert bei $21 \%$ : Press release no. 098, 14/03/2019, Statistisches Bundesamt

Destatis (2020) Gender pay gap. Statistisches Bundesamt. https://www.destatis.de/EN/Themes/Labour/ Labour-Market/Quality-Employment/Dimension1/1_5_GenderPayGap.html. Accessed: 27/10/2020

Francesconi M, Parey M (2018) Early gender gaps among university graduates. Eur Econ Rev 109:63-82

Garritzmann JL (2016) The political economy of higher education finance: the politics of tuition fees and subsidies in OECD countries. Springer, Berlin, pp 1945-2015

Granados PG, Geyer J (2013) Brutto größer als Netto: Geschlechtsspezifische Lohnunterschiede unter Berücksichtigung von Steuern und Verteilung. DIW Wochenbericht 80(28):3-12

Hauschildt K, Vogtle EM, Gwosć C (2018) Social and economic conditions of student life in Europe. Synopsis of indicators. Eurostudent VI 2016-2018

Heckman JJ (1979) Sample selection bias as a specification error. Econometrica 47(1):153

Hussar B, Zhang J, Hein S, Wang K, Roberts A, Cui J, Smith M, Bullock Mann F, Barmer A, Dilig R (2020) The condition of education 2020. U.S. Department of Education. National Center for Education Statistics, Washington, DC

Jann B (2008) The Blinder-Oaxaca decomposition for linear regression models. Stata J 8(4):453-479

Kiessling L, Pinger P, Seegers P, Bergerhoff J (2019) Gender differences in wage expectations: sorting, children, and negotiation styles. CESifo working paper no. 7827

Kleven H, Landais C, Posch J, Steinhauer A, Zweimüller J (2019) Child penalties across countries: evidence and explanations. AEA Pap Proc 109:122-126

Leuze K, Strauss S (2014) Female-typical subjects and their effect on wage inequalities among higher education graduates in Germany. Eur Soc 16(2):275-298

Middendorff E, Apolinarski B, Becker K, Bornkessel P, Brandt T, Heißenberg S, Poskowsky J (2017) The economic and social situation of students in Germany 2016. Summary of the 21st Social Survey of Deutsches Studentenwerk, conducted by the German Centre for Higher Education Research and Science Studies. Federal Ministry of Education and Research (BMBF), Berlin

Niederle M (2017) A gender agenda: a progress report on competitiveness. Am Econ Rev 107(5):115-19

Ochsenfeld F (2014) Why do womens fields of study pay less? A test of devaluation, human capital, and gender role theory. Eur Sociol Rev 30(4):536-548

Rammstedt B, Kemper C, Klein M, Beierlein C, Kovaleva A (2013) A short scale for assessing the big five dimensions of personality-10 item big five inventory (BFI-10). Methoden Daten Analysen 7:233-249 
Reimer D, Schröder J (2006) Tracing the gender wage gap: income differences between male and female university graduates in Germany. Zeitschrift für ArbeitsmarktForschung J. Labour Mark Res 39(2):235-253

Reuben E, Wiswall M, Zafar B (2017) Preferences and biases in educational choices and labour market expectations: shrinking the black box of gender. Econ J 127(604):2153-2186

Yun M-S (2004) Decomposing differences in the first moment. Econ Lett 82(2):275-280

Publisher's Note Springer Nature remains neutral with regard to jurisdictional claims in published maps and institutional affiliations. 